Prepared in cooperation with the DuPage County Stormwater Management Department

\title{
Watershed Data Management (WDM) Database for West Branch DuPage River Streamflow Simulation, DuPage County, Illinois, January 1, 2007, through September 30, 2013
}

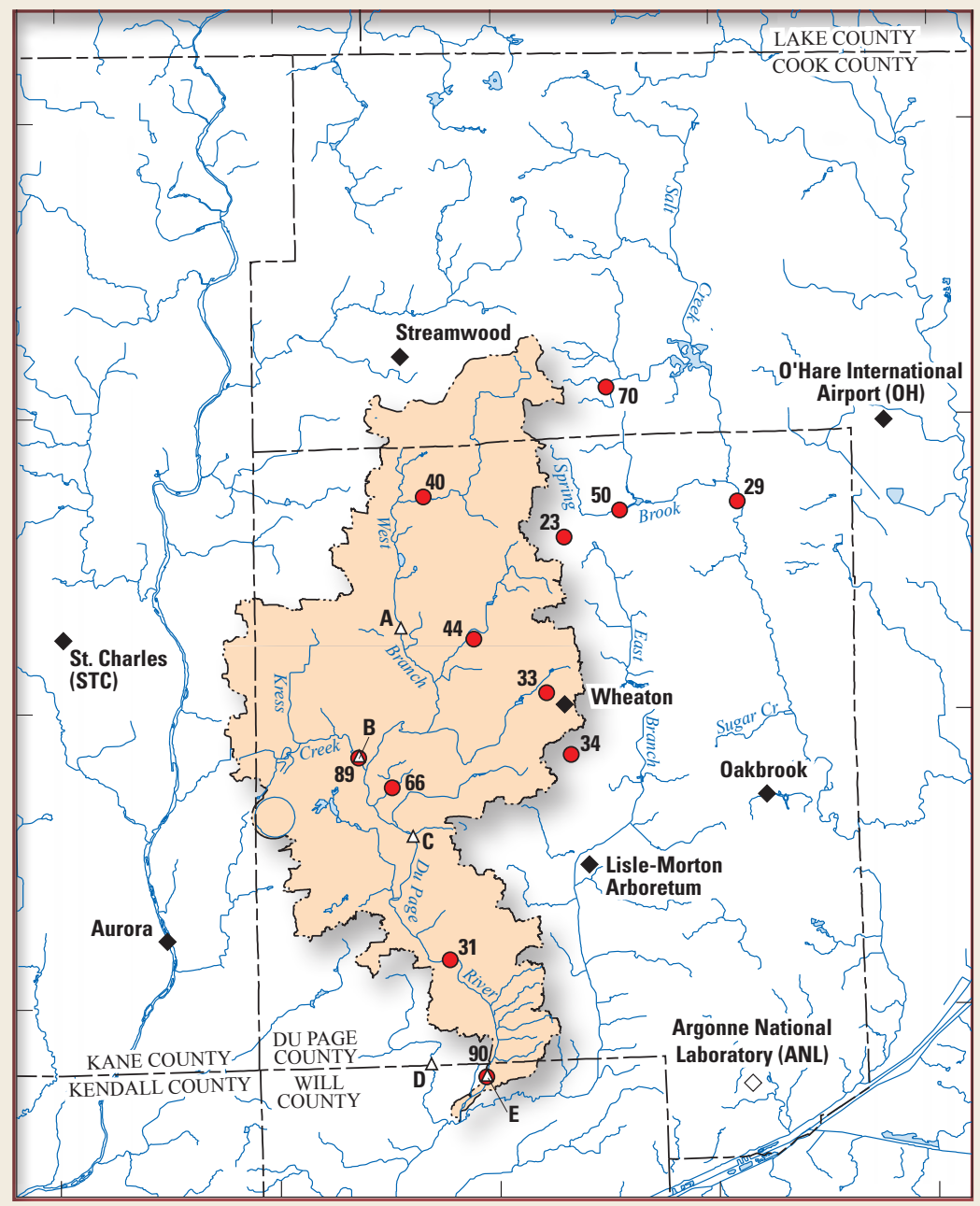

Open-File Report 2017-1099 



\section{Watershed Data Management (WDM) Database for West Branch DuPage River Streamflow Simulation, DuPage County, Illinois, January 1, 2007, through September 30, 2013}

By Maitreyee Bera

Prepared in cooperation with the DuPage County Stormwater Management Department

Open-File Report 2017-1099 


\title{
U.S. Department of the Interior \\ RYAN K. ZINKE, Secretary
}

\section{U.S. Geological Survey William H. Werkheiser, Acting Director}

\author{
U.S. Geological Survey, Reston, Virginia: 2017
}

For more information on the USGS - the Federal source for science about the Earth, its natural and living resources, natural hazards, and the environment-visit https://www.usgs.gov or call 1-888-ASK-USGS.

For an overview of USGS information products, including maps, imagery, and publications, visit https://store.usgs.gov.

Any use of trade, firm, or product names is for descriptive purposes only and does not imply endorsement by the U.S. Government.

Although this information product, for the most part, is in the public domain, it also may contain copyrighted materials as noted in the text. Permission to reproduce copyrighted items must be secured from the copyright owner.

Suggested citation:

Bera, Maitreyee, 2017, Watershed Data Management (WDM) database for West Branch DuPage River streamflow simulation, DuPage County, Illinois, January 1, 2007, through September 30, 2013: U.S. Geological Survey Open-File Report 2017-1099, 39 p., https://doi.org/10.3133/ofr20171099.

ISSN 2331-1258 (online) 


\section{Contents}

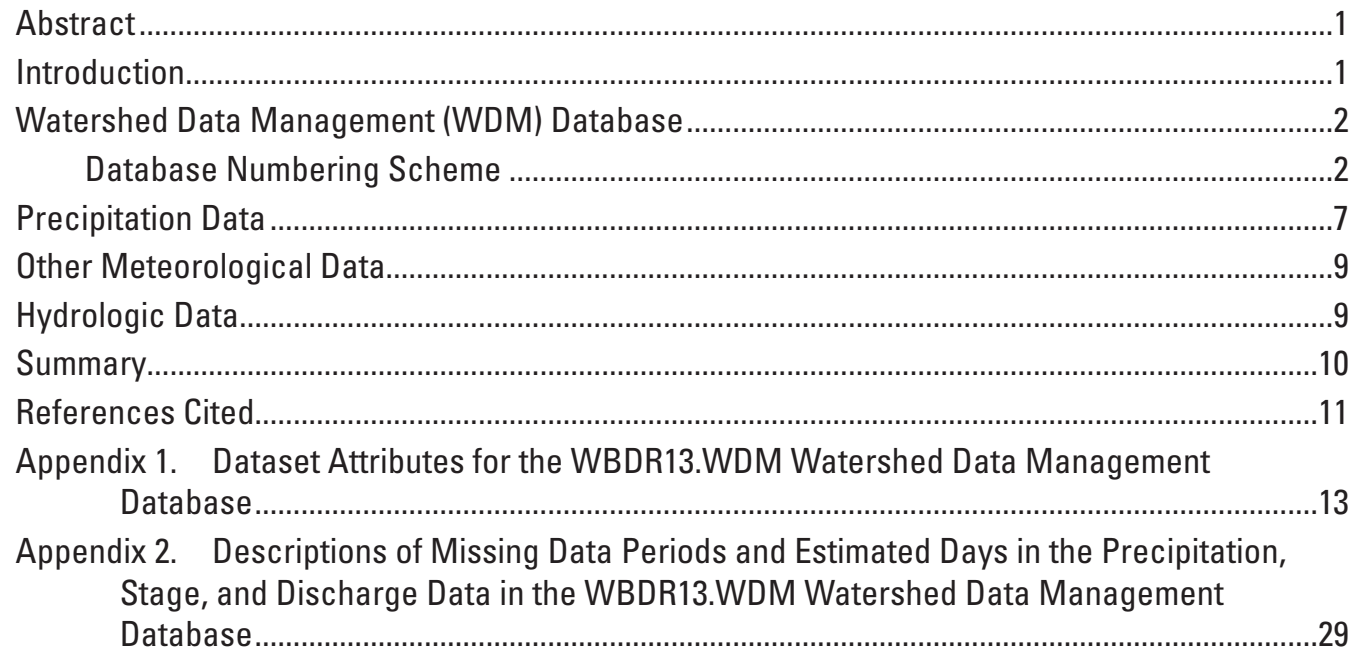

\section{Figures}

1. Map showing the location of the West Branch DuPage River watershed and data-collection sites in and near DuPage County, Illinois.

\section{Tables}

1. Description of dataset numbering system for the data in the WBDR13.WDM database 4

2. List of datasets in the WBDR13.WDM database.

3. Characteristics of rain gages used and selected meteorological data observed during January 1, 2007, through September 30, 2013, in and near DuPage County, Illinois, stored in quality-assured/quality-controlled WBDR13.WDM Watershed Data Management database.

4. National Centers for Environmental Information Observation Stations in Illinois used to determine the snowfall-affected days for the rain gages in and near DuPage County, Illinois, during January 1, 2007, through September 30, 2013.

5. haracteristics of hydrologic data observed in DuPage County, Illinois, stored in WBDR13.WDM Watershed Data Management database.

1-1. Detail dataset attributes for the WBDR13.WDM Watershed Data Management database.

2-1. Missing data periods for real-time network of rain gages along West Branch DuPage River in and near DuPage County, Illinois, January 1, 2007, through September 30, 2013, in the WBDR13.WDM Watershed Data Management database. 


\section{Tables-Continued}

2-2. Snowfall-affected periods for real-time network of rain gages along West Branch DuPage River, in and near DuPage County, Illinois, stored in the WBDR13.WDM Watershed Data Management database, January 1, 2007-September 30, 2013.

2-3. Descriptions of estimated and missing days in river stage data from U.S. Geological Survey streamgages along the West Branch DuPage River, in and near DuPage County, Illinois, stored in the WBDR13.WDM Watershed

Data Management database, for January 1, 2007, through September 30, 2013.

2-4. Descriptions of estimated and missing days in river discharge data from U.S. Geological Survey streamgages along the West Branch DuPage River, in and near DuPage County, Illinois, stored in the WBDR13.WDM Watershed Data Management database, for January 1, 2007, through September 30, 2013.

\section{Conversion Factors}

U.S. customary units to International System of Units

\begin{tabular}{lcl}
\hline \multicolumn{1}{c}{ Multiply } & By & \multicolumn{1}{c}{ To obtain } \\
\hline inch (in.) & Length & millimeter $(\mathrm{mm})$ \\
foot (ft) & 25.4 & meter $(\mathrm{m})$ \\
mile (mi) & 0.3048 & kilometer $(\mathrm{km})$ \\
\hline & 1.609 & \\
\hline square mile $\left(\mathrm{mi}^{2}\right)$ & Area & square kilometer $\left(\mathrm{km}^{2}\right)$ \\
\hline & 2.590 & cubic meter per second $\left(\mathrm{m}^{3} / \mathrm{s}\right)$ \\
\hline cubic foot per second $\left(\mathrm{ft}{ }^{3} / \mathrm{s}\right)$ & Flow rate & meter per hour $(\mathrm{m} / \mathrm{h})$ \\
inch per hour (in $/ \mathrm{h})$ & 0.02832 & meter per day $(\mathrm{m} / \mathrm{d})$ \\
inch per day (in $/ \mathrm{d})$ & 0.0254 & \\
\hline & 0.0254 & watts per square $\mathrm{meter}\left(\mathrm{W} / \mathrm{m}^{2}\right)$ \\
\hline Langleys per hour $(\mathrm{Lg} / \mathrm{hr})$ & Energy flux density & \\
\hline
\end{tabular}

Temperature in degrees Fahrenheit $\left({ }^{\circ} \mathrm{F}\right)$ may be converted to degrees Celsius $\left({ }^{\circ} \mathrm{C}\right)$ as follows:

$$
{ }^{\circ} \mathrm{C}=\left({ }^{\circ} \mathrm{F}-32\right) / 1.8 \text {. }
$$

\section{Datum}

Vertical coordinate information is referenced to the National Geodetic Vertical Datum of 1929 (NGVD 29).

Horizontal coordinate information is referenced to the North American Datum of 1983 (NAD 83) and the North American Datum of 1927 (NAD 27). 


\section{Abbreviations}

$\begin{array}{ll}\text { ADAPS } & \text { USGS Automated Data Processing System } \\ \text { ANL } & \text { Argonne National Laboratory } \\ \text { FEO } & \text { Full Equations hydraulic model } \\ \text { BASINS } & \text { Better Assessment Science Integrating point and Non-point Sources } \\ \text { GenScn } & \text { Generation and Analysis of Model Simulation Scenarios } \\ \text { HSPF } & \text { Hydrological Simulation Program-FORTRAN } \\ \text { HYDHR } & \text { HSPF hourly-observations } \\ \text { MAGIC } & \text { Meteorological and hydrologic GenScn input converter } \\ \text { OA/OC } & \text { Quality-assured and quality-controlled } \\ \text { USGS } & \text { U.S. Geological Survey } \\ \text { WBDR } & \text { West Branch DuPage River } \\ \text { WDM } & \text { Watershed Data Management } \\ \text { DSN } & \text { Dataset number } \\ \text { WY } & \text { Water year } \\ \text { WDR } & \text { USGS Annual Water Data Reports }\end{array}$





\title{
Watershed Data Management (WDM) Database for West Branch DuPage River Streamflow Simulation, DuPage County, Illinois, January 1, 2007, through September 30, 2013
}

\author{
By Maitreyee Bera
}

\begin{abstract}
The U.S. Geological Survey (USGS), in cooperation with the DuPage County Stormwater Management Department, maintains a database of hourly meteorological and hydrologic data for use in a near real-time streamflow simulation system. This system is used in the management and operation of reservoirs and other flood-control structures in the West Branch DuPage River watershed in DuPage County, Illinois. The majority of the precipitation data are collected from a tippingbucket rain gage network located in and near DuPage County. The other meteorological data (air temperature, dewpoint temperature, wind speed, and solar radiation) are collected at Argonne National Laboratory in Argonne, Ill. Potential evapotranspiration is computed from the meteorological data using the computer program LXPET (Lamoreux Potential Evapotranspiration). The hydrologic data (water-surface elevation [stage] and discharge) are collected at USGS streamgages in and around DuPage County. These data are stored in a Watershed Data Management (WDM) database.

This report describes a version of the WDM database that is quality-assured and quality-controlled annually to ensure datasets are complete and accurate. This database is named WBDR13.WDM. It contains data from January 1, 2007, through September 30, 2013. Each precipitation dataset may have time periods of inaccurate data. This report describes the methods used to estimate the data for the periods of missing, erroneous, or snowfall-affected data and thereby improve the accuracy of these data. The meteorological datasets other than precipitation (air temperature, dewpoint temperature, wind speed, solar radiation, and potential evapotranspiration) are copied from ARGN14.WDM and stored in WBDR13.WDM, and the hydrologic datasets in the database are fully described in the online USGS annual water data reports for Illinois and, therefore, are described in less detail than the precipitation datasets in this report.
\end{abstract}

\section{Introduction}

The U.S. Geological Survey (USGS), in cooperation with the DuPage County Stormwater Management Department, maintains a database of hourly meteorological and hydrologic data for use in a near real-time streamflow simulation system. This system is used in the management and operation of reservoirs and other flood-control structures in the West Branch DuPage River (WBDR) watershed in DuPage County, Illinois. The USGS and DuPage County currently (2017) use the Hydrological Simulation Program-FORTRAN (HSPF) hydrologic model (Bicknell and others, 2000) and Full Equations (FEQ) hydraulic model (Franz and Melching, 1997) to develop the simulations of the watershed rainfall runoff (HSPF) and routed streamflow (FEQ) at a 1-hour time step. The Watershed Data Management (WDM) database was designed for use with the HSPF model to store input and output data files. This report focuses on the processing and the data organization of the WDM database WBDR13.WDM that is used in the near real-time streamflow simulation system for WBDR watershed in DuPage County, Ill. It does not describe how HSPF and FEQ models are used in the real-time streamflow simulation system. For a related reference, see Ishii and others (1998), which describes in detail how HSPF and FEQ are used in near real-time streamflow simulation system for Salt Creek watershed in DuPage county Ill.

The meteorological and hydrologic data are collected at various sites in and near DuPage County (fig. 1). These provisional data are stored in a WDM database that is updated at least weekly by USGS staff. The provisional data may have periods of missing or flawed data due to equipment malfunctions or other problems. To improve the accuracy of simulations, the WDM database is updated and corrected with quality-assured and quality-controlled (QA/QC) data for each water year (WY; a water year is the 12-month period October 1 through September 30 and is designated by the calendar year 
in which it ends). This update is done to maintain a record of the data in a model-compatible format and for studying historical storms. Although this database is compiled for the WBDR watershed, the data could be used in other hydrologic models in northeastern Illinois or by scientists studying rain distribution or climate in the area.

The purpose of this report is to describe the data sources and data organization used to create the $\mathrm{QA} / \mathrm{QC}$ version of the WDM database, including how periods of missing or inaccurate precipitation data are estimated. The QA/QC database discussed in this document encompasses the period from January 1, 2007, through September 30, 2013, and is named the WBDR13.WDM. Detailed explanations of the hydrologic data are given in the documentation of the USGS Annual Water Data Report (U.S. Geological Survey, 2016). This documentation is available online at https://wdr.water.usgs.gov/current/ documentation.html. Over and others (2010) describe in detail the methods used to fill in missing and erroneous meteorological data (air temperature, dewpoint temperature, wind speed, and solar radiation). These documentations will not be repeated in his report.

\section{Watershed Data Management (WDM) Database}

The WDM database is a binary, direct-access electronic file (Flynn and others, 1995). It was developed by the USGS to be used with hydrologic and water-quality models and analyses. Data within the WDM database are stored in datasets. WDM databases can be accessed with the ANNIE computer program (Flynn and others, 1995); with the Generation and Analysis of Model Simulation Scenarios (GenScn), an interactive computer program (Kittle and others, 1998); or with Better Assessment Science Integrating point and Non-point Sources (BASINS), a multipurpose environmental analysis system. The WBDR13.WDM database contains meteorological and hydrologic data collected in and near DuPage County, Illinois. The WDM database WBDR13.WDM and its associated metadata (Bera, 2017) are available at https://doi. org/10.5066/F71Z42M0. The data organization, sources, and $\mathrm{QA} / \mathrm{QC}$ procedures are discussed below.

\section{Database Numbering Scheme}

To aid in identifying the contents of WDM datasets, dataset numbers (DSNs) are assigned in a systematic order. The DSNs are limited to four digits in the Hydrological Simulation Program-FORTRAN (HSPF) model, which uses the WDM.

Up to 32,000 datasets are allowed in the WDM database, but access to these datasets requires a direct-access computer program such as ANNIE. In the WBDR13.WDM, all DSNs are between 1 and 7019 .

The data are numbered in the WDM database according to data type and the location from which the data were gathered. Generally, the different data types are grouped into series (table 1). For example, the dataset numbers from 100 to 199 are for precipitation. The last two digits of the DSN indicate the station identification or location of the data source. The last two digits are based on the DuPage County site identifier for rain gages (fig. 1). In addition to hourly meteorological data, WBDR13.WDM contains hourly data flags describing each of the four meteorological data types: air temperature, dewpoint temperature, wind speed, and solar radiation. Each hourly data flag time series is assigned a three digit DSN. The second and third digits are 1 and 0 respectively. The first digit is the same as that of the corresponding meteorological data type DSN. These data flags are described in detail in Over and others (2010) and Bera (2014).

For hydrologic data, a four-digit DSN is used; the first two digits of the number indicate the type and location of the data, and the third and fourth digits are 00 if the data are observed. There are a few exceptions to the observed data label of 00 . The complete list of datasets in WBDR13.WDM database is given in table 2, and a list of dataset attributes is given in Appendix 1.

As can be seen from table 2, WBDR13.WDM contains many datasets that are not part of the annual QA/QC process. These datasets have been created in the WDM database for data analyses or for convenience of data processing. For example, dataset 1 contains a constant arithmetic value used to generate a datum for the water-surface elevations. Datasets 107 and 801-811 are used in comparisons of precipitation data. Datasets 6107-7019 are used in model simulation outputs for reviewing model operations. 


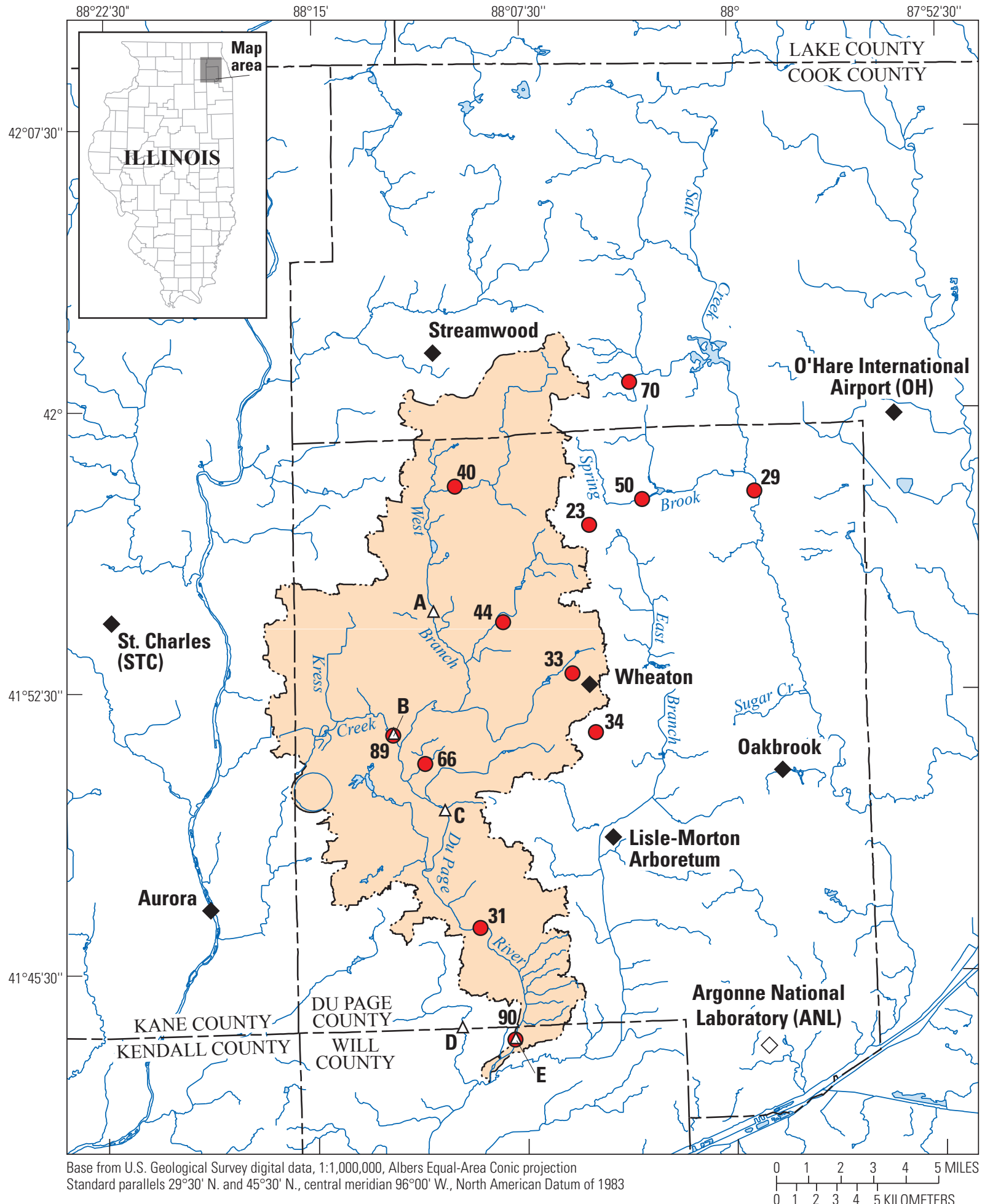

EXPLANATION

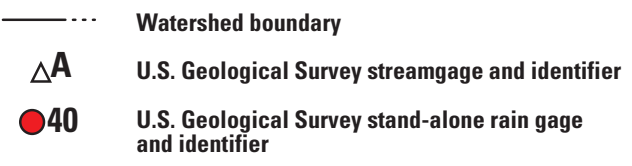

$\diamond$ Meteorological station

National Centers for Environmental Information weather observation station. Not shown: Plainfield, approximately 7 miles downstream of stream gage $\mathrm{E}$, and Romeoville, approximately 9.5 miles southwest of Argonne National Laboratory

Figure 1. Location of the West Branch DuPage River watershed and data-collection sites in and near DuPage County, Illinois. 
Table 1. Description of dataset numbering system for the data in the WBDR13.WDM database.

[The impervious and pervious runoff datasets are used to store output from the hydrologic model simulations; the data stored therein change with each model run. USGS, U.S. Geological Survey; IDCON, identification of data type; NEXRAD, Next Generation Radar; ISUR, runoff from impervious surfaces; PERO, runoff from pervious surfaces]

\begin{tabular}{cll}
\hline Dataset numbers & \multicolumn{1}{c}{ Data type } & \multicolumn{1}{c}{ IDCON attribute } \\
\hline & \multicolumn{1}{c}{ General data } \\
\hline $1-10$ & \multicolumn{1}{c}{ Matums } & ELEV. \\
\hline $100-199$ & Precipitation from tipping bucket gages & PREC. \\
$200-299$ & Potential evapotranspiration & EVAP. \\
$300-399$ & Wind speed & WIND. \\
$400-499$ & Air temperature & TEMP. \\
$500-599$ & Dewpoint temperature & DEWP. \\
$600-699$ & Solar radiation & SRAD. \\
$800-899$ & Computed NEXRAD precipitation & PREC. \\
& \multicolumn{1}{c}{ Hydrologic data } & \\
\hline $2000-2999$ & Discharge & FLOW. \\
$4000-4999$ & Water-surface elevation from USGS gages & ELEV. \\
$6000-6999$ & Hydrologic model output & ISUR/PERO. \\
$7000-7999$ & Simulated flow components & Various. \\
\hline
\end{tabular}


Table 2. List of datasets in the WBDR13.WDM database.

[DSN, dataset number; Description, station name, location, and information about the units used; TSTYPE, type of data; ft, feet; ELEV, elevation; in., inch; PREC, precipitation; Bldg., building; Ill., Illinois; WWTF, wastewater treatment facility; EVAP, evapotranspiration; WIND, wind speed; FLAG, hourly data flag; TEMP, air temperature; ${ }^{\circ}$ F, degrees Fahrenheit; DEWP, dewpoint; SRAD, solar radiation; NEXRAD, Next Generation Radar; AVG, average; WBDR, West Branch DuPage River; Trib, tributary; FLOW, discharge; ft³/s, cubic feet per second; NGVD 29, National Geodetic Vertical Datum of 1929; in/hr, inches per hour; *, multiply by; mi $^{2}$, square mile; ISUR, runoff from impervious surfaces; PERO, runoff from pervious surfaces; SURO, surface outflow; IFWO, interflow outflow; in/d, inch per day; PET, potential evapotranspiration; ET, evapotranspiration; TAET, simulated evapotranspiration; UZS, upper zone storage; LZS, lower zone storage; AGWS, groundwater storage at start; SNOW, simulated snow depth]

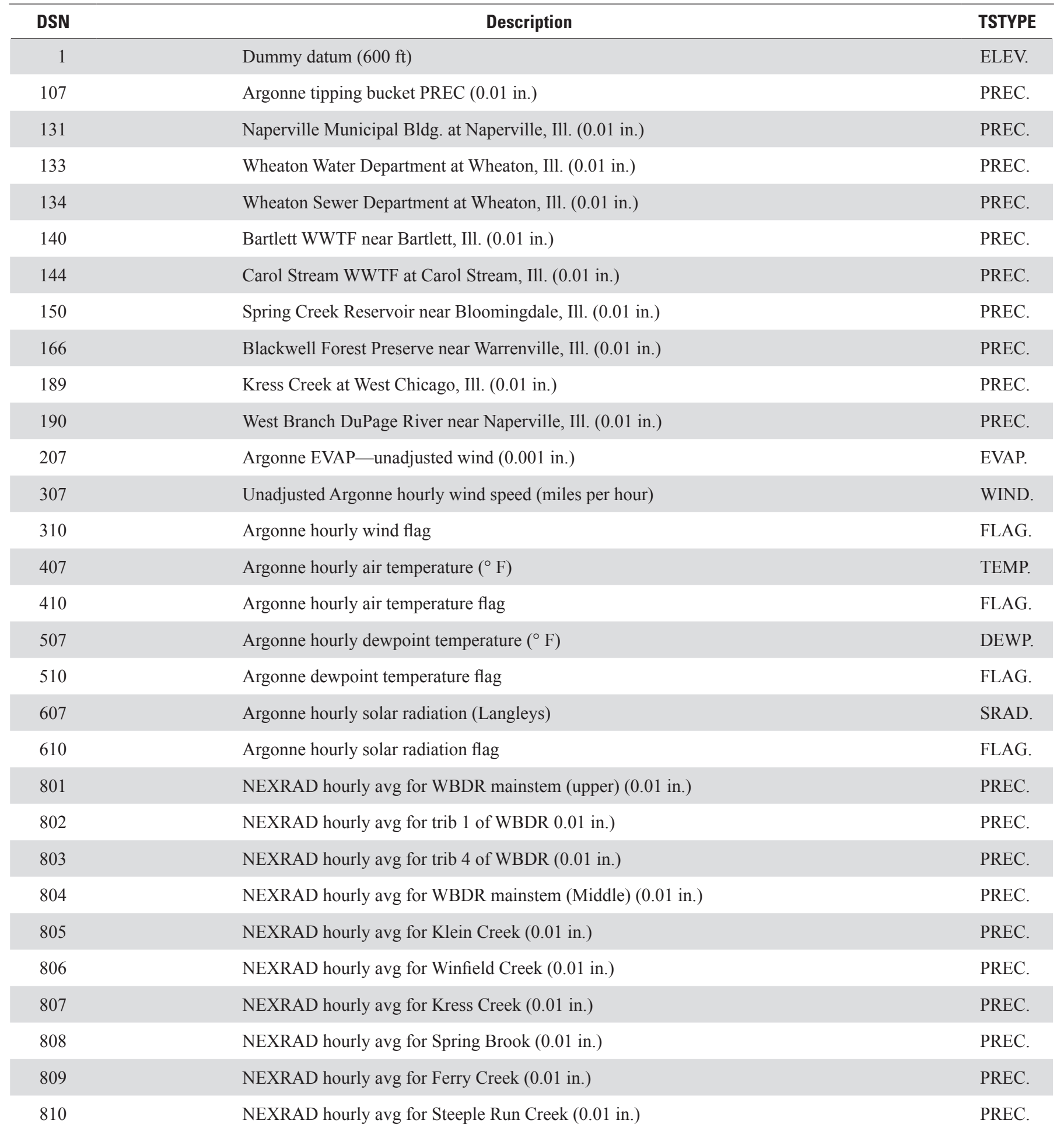


Table 2. List of datasets in the WBDR13.WDM database.-Continued

[DSN, dataset number; Description, station name, location, and information about the units used; TSTYPE, type of data; ft, feet; ELEV, elevation; in., inch; PREC, precipitation; Bldg., building; Ill., Illinois; WWTF, wastewater treatment facility; EVAP, evapotranspiration; WIND, wind speed; FLAG, hourly data flag; TEMP, air temperature; ${ }^{\circ}$ F, degrees Fahrenheit; DEWP, dewpoint; SRAD, solar radiation; NEXRAD, Next Generation Radar; AVG, average; WBDR, West Branch DuPage River; Trib, tributary; FLOW, discharge; fts/s, cubic feet per second; NGVD 29, National Geodetic Vertical Datum of 1929; in/hr, inch per hour; *, multiply by; $\mathrm{mi}^{2}$, square mile; ISUR, runoff from impervious surfaces; PERO, runoff from pervious surfaces; SURO, surface outflow; IFWO, interflow outflow; in/d, inch per day; PET, potential evapotranspiration; ET, evapotranspiration; TAET, simulated evapotranspiration; UZS, upper zone storage; LZS, lower zone storage; AGWS, groundwater storage at start; SNOW, simulated snow depth]

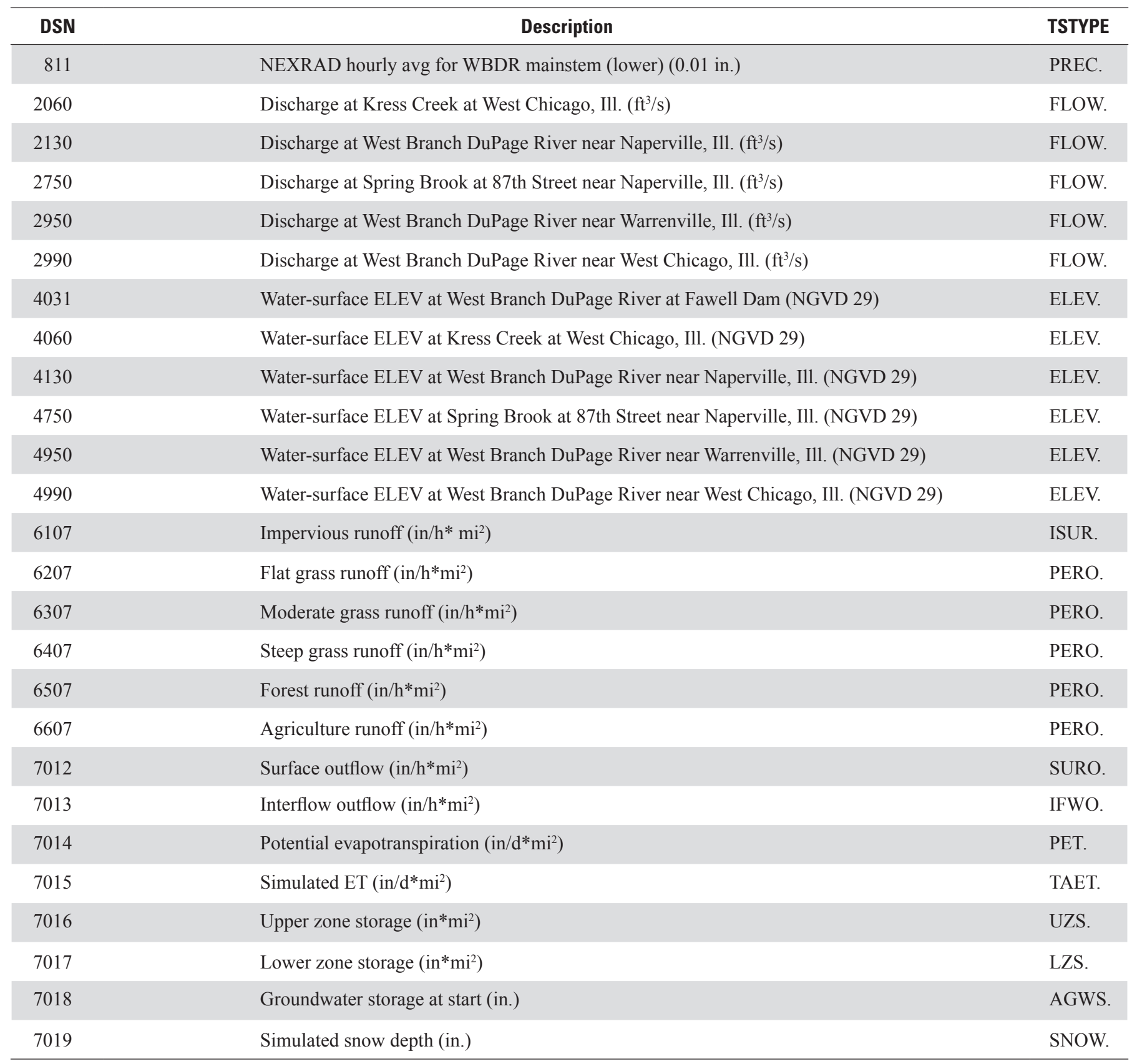




\section{Precipitation Data}

The source of precipitation data in the QA/QC WDM is the USGS and DuPage County real-time flood-warning rain gage network. The real-time flood-warning rain gage network contains 8 rain gages $(31,33,34,40,44,66,89$, and 90 ; table 3) in and near the West Branch DuPage River watershed (fig. 1). The real-time flood-warning rain gage network consists of 6-, 8-, and 12-inch (in.) diameter tipping-bucket rain gages. These tipping-bucket rain gages are set to tip when $0.01 \mathrm{in}$. of rain has been collected in the gage. Some of the gages in the network are heated, thus allowing them to record snowfall amounts (table 3 ). Some of the rain gages have radio telemetry, which transmits the data to a DuPage County facility at every 5 minutes (table 3 ).

Most of the rain gages with radio telemetry also have an onsite data logger that records the data. Files from the data logger are downloaded by USGS personnel during site visits. Data collected with a data logger are generally more reliable than data transmitted by a radio telemetry, because transmission failures are avoided. When the data logger is missing data, radio-transmitted data are used as a backup record at the gages. If there is no backup record available at the gage, then gaps when data are missing are filled with data from a nearby gage. The rain gage data from 23 (USGS 415651088051900 , Bloomingdale Lift Station at Bloomingdale, Ill., located at $41^{\circ} 56^{\prime} 51^{\prime \prime}, 88^{\circ} 05^{\prime} 19^{\prime \prime}$ ), 29 (USGS 415751087591000 , Wood Dale WWTF at Wood Dale, Ill., located at 41 ${ }^{\circ} 57^{\prime} 51^{\prime \prime}$, $87^{\circ} 59^{\prime} 10^{\prime \prime}$ ), 50 (USGS 415737088031100, Spring Creek Reservoir near Bloomingdale, Ill., located at 41 ${ }^{\circ} 57^{\prime} 37^{\prime \prime}$, $88^{\circ} 03^{\prime} 11^{\prime \prime}$ ), and 70 (USGS 420052088034200 , Schaumburg Public Works at Schaumburg, Ill., located at $42^{\circ} 00^{\prime} 52^{\prime \prime}$, $88^{\circ} 03^{\prime} 42^{\prime \prime}$ ) near the West Branch DuPage River watershed are used as a backup. The QA/QC processing of the data from these gages are described in detail in Bera (2014).

The data from the rain gage network were checked for accuracy and processed for publication in the USGS Annual WDR. Missing data are flagged as "--" and snowfall-affected data are flagged as "e" in the WDR. Snowfall-affected data were flagged for heated and unheated rain gages. Snowfallaffected data were flagged because unheated rain gages inaccurately record precipitation data at temperatures below freezing. Frozen precipitation, usually in the form of snow, accumulates in the funnel of unheated rain gages. This frozen precipitation is measured when it melts. Wind can blow snow out of the rain gage before it can melt, thus leaving some precipitation unmeasured. The determination of which data were affected by snowfall took into consideration the air temperature data obtained from the nearby National Centers for Environmental Information weather observation stations (fig. 1; National Centers for Environmental Information, 2017) from the Illinois network listed in table 4, the placement of the rain gage, and the amount of precipitation observed at heated rain gages in the network. The weather observation station is chosen by the hydrographer working on the record for a specific rain gage. Missing data are filled from nearby rain gages as a part of the $\mathrm{QA} / \mathrm{QC}$ process and stored in the WDM database. Unit value precipitation data from January 1, 2007, through September 30, 2013, were retrieved from the USGS Automated Data Processing System (ADAPS) database (U.S. Geological Survey, 2015) and were used as the basis for the QA/QC of the WDM database. Unit value precipitation data are the incremental data collected by the recorder (data logger at the data site) or computed from the recorded incremental data. Unit value data are often recorded in 15-minute increments. ADAPS unit value data were processed into hourly values by using the meteorological and hydrologic GenScn input converter (MAGIC) computer program (Ortel and Martin, 2010). Any missing hourly value of precipitation was filled with the corresponding data from a nearby network gage. These data were then input to WBDR13.WDM. For each station, the estimated data were determined by consulting the USGS Annual WDR (U.S. Geological Survey, 2016) for Illinois, which identified days with estimated rainfall with snowmelt and days with partial records. Appendix table 2-1 describes all of the missing periods and the stations used to fill in the missing data. Appendix table 2-2 lists the snowfallaffected periods. 
Table 3. Characteristics of rain gages used and selected meteorological data observed during January 1, 2007, through September 30, 2013, in and near DuPage County, Illinois, stored in quality-assured/quality-controlled WBDR13.WDM Watershed Data Management database.

[USGS, U.S. Geological Survey; WDM, Watershed Data Management; ANL, Argonne National Laboratory; PREC, precipitation; - , not applicable; in., inch; Lat, latitude given as: degrees $\left({ }^{\circ}\right)$ minutes $(')$ seconds ("); Long, longitude given as: degrees $\left({ }^{\circ}\right)$ minutes $(')$ seconds $(")$; ${ }^{\circ}$ F, degrees Fahrenheit; EVAP, potential evapotranspiration; Bldg., Building; Ill., Illinois; Y, Yes; WWTF, Wastewater Treatment Facility]

\begin{tabular}{|c|c|c|c|c|c|c|}
\hline $\begin{array}{l}\text { Site } \\
\text { identifier } \\
\text { (fig. 1) }\end{array}$ & $\begin{array}{l}\text { Dataset } \\
\text { number }\end{array}$ & $\begin{array}{l}\text { Location of gage } \\
\text { (USGS station number) }\end{array}$ & $\begin{array}{c}\text { Data type } \\
\text { (unit of measurement) }\end{array}$ & $\begin{array}{c}\text { Radio } \\
\text { telemetry } \\
\text { (yes or no) }\end{array}$ & $\begin{array}{l}\text { Period of record in } \\
\text { WBDR13.wdm } \\
\text { database } \\
\text { (month/day/year) }\end{array}$ & $\begin{array}{c}\text { Rain gage } \\
\begin{array}{c}\text { Water } \\
\text { year heated }\end{array}\end{array}$ \\
\hline \multirow[t]{10}{*}{ ANL } & 107 & Argonne National Laboratory & PREC (0.01 in.) & - & $01 / 01 / 1996-09 / 30 / 2013$ & - \\
\hline & 307 & 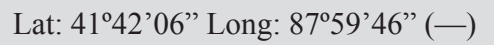 & Air temperature $\left({ }^{\circ} \mathrm{F}\right)$ & - & 01/01/1996-09/30/2013 & - \\
\hline & 310 & & Air temperature flag $(-)$ & - & 01/01/1996-09/30/2013 & - \\
\hline & 607 & & $\begin{array}{l}\text { Dewpoint temperature } \\
\quad(\operatorname{deg} \mathrm{F})\end{array}$ & - & 01/01/1996-09/30/2013 & - \\
\hline & 610 & & $\begin{array}{l}\text { Dewpoint temperature flag } \\
(-)\end{array}$ & - & 01/01/1996-09/30/2013 & - \\
\hline & 407 & & Wind speed (miles per hour) & - & 01/01/1996-09/30/2013 & - \\
\hline & 410 & & Wind speed flag $(-)$ & - & 01/01/1996-09/30/2013 & - \\
\hline & 507 & & Solar radiation (Langleys) & - & 01/01/1996-09/30/2013 & - \\
\hline & 510 & & Solar radiation flag $(-)$ & - & 01/01/1996-09/30/2013 & - \\
\hline & 207 & & $\operatorname{EVAP}(0.001$ in. $)$ & - & 01/01/1996-09/30/2013 & - \\
\hline 31 & 131 & $\begin{array}{l}\text { Naperville Municipal Bldg. at Naper- } \\
\text { ville, Ill. } \\
\text { Lat: } 41^{\circ} 46^{\prime} 13^{\prime \prime} \text { Long: } 88^{\circ} 09^{\prime} 10^{\prime \prime} \\
\text { (414613088091000) }\end{array}$ & $\operatorname{PREC}(0.01$ in.) & $\mathrm{Y}$ & $01 / 01 / 2007-09 / 30 / 2013$ & 2007,2008 \\
\hline 33 & 133 & $\begin{array}{l}\text { Wheaton Water Department at Whea- } \\
\text { ton, Ill. } \\
\text { Lat: } 41^{\circ} 53^{\prime} 00^{\prime \prime} \text { Long: } 88^{\circ} 05^{\prime} 46^{\prime \prime} \\
\text { (415300088054600) }\end{array}$ & PREC (0.01 in.) & $\mathrm{Y}$ & $01 / 01 / 2007-09 / 30 / 2013$ & $\begin{array}{l}2007,2008, \\
2011,2012, \\
2013\end{array}$ \\
\hline 34 & 134 & $\begin{array}{l}\text { Wheaton Sewer Department at Whea- } \\
\text { ton, Ill. } \\
\text { Lat: } 41^{\circ} 51^{\prime} 25^{\prime} \text { Long: } 88^{\circ} 04^{\prime} 57^{\prime \prime} \\
\text { (415125088045700) }\end{array}$ & PREC (0.01 in.) & $\mathrm{Y}$ & 01/01/2007-09/30/2013 & $\begin{array}{l}2007,2008, \\
2011,2012\end{array}$ \\
\hline 40 & 140 & $\begin{array}{l}\text { Bartlett WWTF near Bartlett, Ill. } \\
\text { Lat: } 41^{\circ} 58^{\prime} 01^{\prime} \text { Long } 88^{\circ} 09^{\prime} 57^{\prime \prime} \\
(415801088095700)\end{array}$ & PREC (0.01 in.) & $\mathrm{Y}$ & 01/01/2007-09/30/2013 & None. \\
\hline 44 & 144 & $\begin{array}{l}\text { Carol Stream WWTF at Carol } \\
\text { Stream, Ill. } \\
\text { Lat: } 41^{\circ} 54 ' 23 \text { ' Long } 88^{\circ} 08^{\prime} 15^{\prime} \text {, } \\
(41523088081500)\end{array}$ & PREC (0.01 in.) & $\mathrm{Y}$ & 01/01/2007-09/30/2013 & None. \\
\hline${ }^{2} 66$ & 166 & $\begin{array}{l}\text { Blackwell Forest Preserve near } \\
\text { Warrenville, Ill. } \\
\text { Lat: } 41^{\circ} 50^{\prime} 37^{\prime} \text { Long: } 88^{\circ} 11^{\prime} 06 \text { ' } \\
\text { (415037088110600) }\end{array}$ & PREC (0.01 in.) & $\mathrm{Y}$ & 01/01/2007-09/30/2013 & None. \\
\hline 89 & 189 & $\begin{array}{l}\text { Kress Creek at West Chicago, Ill. } \\
\text { Lat: } 41^{\circ} 51^{\prime} 23^{\prime \prime} \text { Long } 88^{\circ} 12^{\prime} 14^{\prime \prime} \\
(05540060)\end{array}$ & PREC (0.01 in.) & $\mathrm{Y}$ & $01 / 01 / 2007-09 / 30 / 2013$ & None. \\
\hline 90 & 190 & $\begin{array}{l}\text { West Branch DuPage River near } \\
\text { Naperville, Ill. } \\
\text { Lat: } 41^{\circ} 43 \text { '13' Long: } 88^{\circ} 07^{\prime} 55^{\prime} \text {, } \\
\text { (05540130) }\end{array}$ & PREC (0.01 in.) & $\mathrm{Y}$ & $01 / 01 / 2007-09 / 30 / 2013$ & None. \\
\hline
\end{tabular}

'Information not available for WY09 (except for rain gage 89).

${ }^{2}$ Rain gage 66 was removed permanently on $08 / 27 / 13$. 
Table 4. National Centers for Environmental Information Observation Stations in Illinois used to determine the snowfall-affected days for the rain gages in and near DuPage County, Illinois, during January 1, 2007, through September 30, 2013.

\begin{tabular}{ccl}
\hline $\begin{array}{c}\text { Site } \\
\text { identifier } \\
\text { (fig. 1) }\end{array}$ & $\begin{array}{c}\text { Dataset } \\
\text { number }\end{array}$ & \multicolumn{1}{c}{$\begin{array}{c}\text { Weather observation stations used } \\
\text { (water year) }\end{array}$} \\
\hline 31 & 131 & Romeoville (2007); Plainfield (2010); Aurora (2011, 2012, 2013). \\
33 & 133 & Wheaton (2007); Oakbrook (2010); O’Hare International Airport (2011, 2012, 2013). \\
34 & 134 & Wheaton (2007); Oakbrook (2010); O'Hare International Airport (2011, 2012, 2013). \\
40 & 140 & O’Hare International Airport (2007, 2008); Streamwood (2010); Aurora (2011, 2012, 2013). \\
44 & 144 & Wheaton (2007, 2008); Oakbrook (2010); Aurora (2011, 2012, 2013). \\
66 & 166 & Wheaton (2007, 2008); Lisle-Morton Arboretum (2010); Aurora (2011, 2012, 2013). \\
89 & 189 & Aurora and St. Charles (2007, 2008); Aurora (2009, 2010, 2011, 2012, 2013). \\
90 & 190 & Romeoville (2007, 2008); Aurora (2010, 2011, 2012, 2013). \\
\hline
\end{tabular}

\section{Other Meteorological Data}

The U.S. Department of Energy facility, Argonne National Laboratory (ANL), is the main source of meteorological data in the WDM database. The air temperature, dewpoint temperature, wind speed, and solar radiation data were obtained from the ANL Web site (Argonne National Laboratory, 2015). Any missing data were estimated to provide a full and accurate data record in the WDM database. The data were quality controlled by ANL staff (Argonne National Laboratory, 2015); however, these data still required adjustment to account for different data-collection methods at the ANL station over the period of record. Missing and erroneous values were estimated from adjusted meteorological data derived from the backup weather observation stations at St. Charles, Ill., and O'Hare International Airport, Chicago, Ill. (fig. 1). As described in Over and others (2010), the adjustments were computed based on the regressions between the primary data series from ANL and the backup series from the meteorological stations at St. Charles and O'Hare by using data obtained during common periods. Each hourly meteorological data value is assigned a corresponding data-source flag denoted by a three-digit code in the form "xyz" (Over and others, 2010). These flags provide complete information regarding the origin and transformations of each hourly value in the database. In addition to the hourly meteorological data, WBDR13.WDM contains those data-source flags describing the meteorological data.

Details of these regression equations and data-source flags are documented in Over and others (2010). The regression equation for solar radiation is changed based on the regression analysis of the backup data series at St. Charles for WYs 2008-10 as described in Bera (2014). Potential evapotranspiration is computed from the meteorological data according to the method described in Murphy (2005).

\section{Hydrologic Data}

In addition to the meteorological data used as inputs to the HSPF model, WBDR13.WDM contains datasets of observed discharge and water-surface elevation (stage). These data are used to compare the simulated discharges generated by HSPF and water-surface elevations generated by FEQ. The stage data are measured at five USGS streamgages (table 4), and the discharge data are computed from these stage data.

The discharge data are estimated when stage data are missing or when the stage-discharge relation is temporarily not valid, such as for backwater conditions. The daily mean estimated discharge data are flagged "e" and missing stage data are flagged "- " in the USGS Annual WDR (U.S. Geological Survey, 2016). The corresponding computed and approved unit value discharge data in ADAPS are assigned a flag "U" for all of the time steps for that day. Missing stage data are identified as "-123456E20" in the data file for unit value stage in ADAPS. Unit value stage and discharge data are recorded in 5-minute increments. Hourly stage and discharge data from January 1 , 2007, to September 30, 2013, were retrieved from ADAPS and were processed by using MAGIC (Ortel and Martin, 2010). The MAGIC processing creates a file in HSPF hourly-observations (HYDHR) file format (Ortel and Martin, 2010) in which it writes "-99.9" for each "U" flag in the file of unit value discharge and "-99.9" for each "-123456E20" flag in the file of unit value stage data. Unit value stage data are instantaneous data collected by the data logger at the site. The unit value stage data in ADAPS lack the correction to the National Geodetic Vertical Datum (NGVD) of 1929, but user control input (uci) file for HSPF is written such that the correct datum is added and the resultant elevation data are stored in the WDM file. These HSPF HYDHR files are written to WBDR13.WDM by using an HSPF uci file. Appendix tables 2-3 and 2-4 describe the periods of missing data for stage and estimated data for discharge. 
Table 5. Characteristics of hydrologic data observed in DuPage County, Illinois, stored in WBDR13.WDM Watershed Data Management database.

[USGS, U.S. Geological Survey; WDM. Watershed Data Management; IDCON, constituent identification attribute in WDM database; Ill., Illinois; ft, feet; NGVD 29, National Geodetic Vertical Datum of 1929; dates are expressed as month/day/year; ELEV, water-surface elevation; FLOW, discharge]

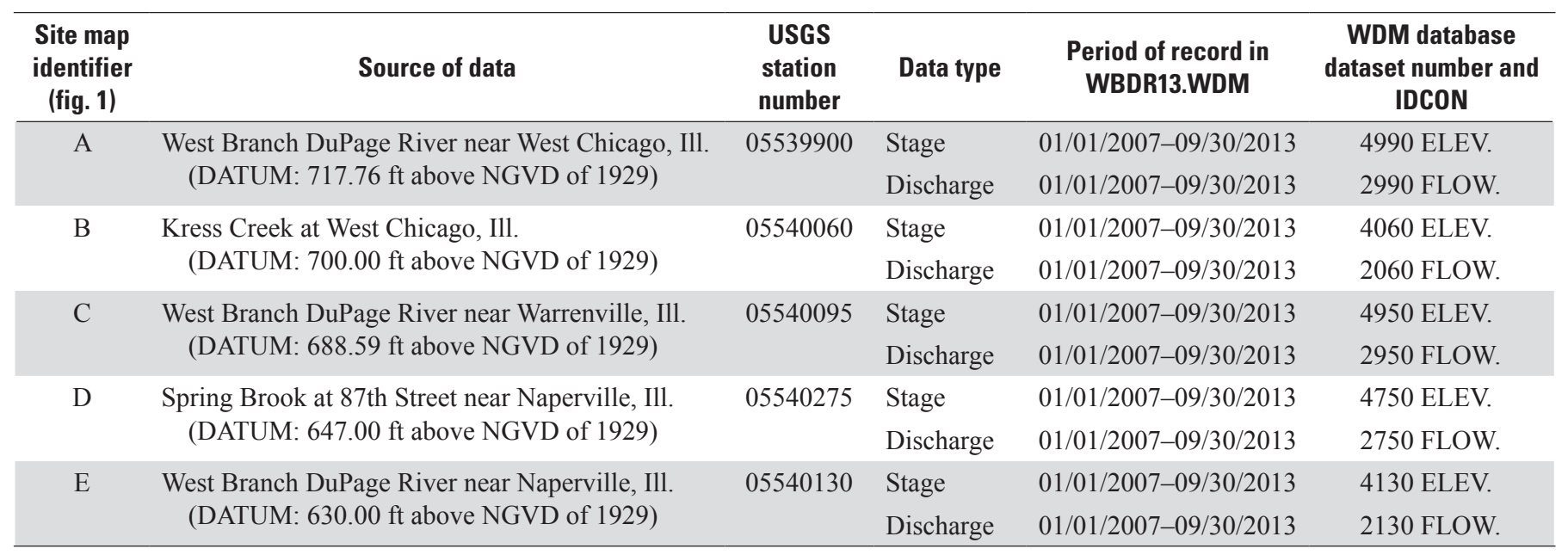

\section{Summary}

The U.S. Geological Survey (USGS), in cooperation with DuPage County Stormwater Management Department, maintains a database of hourly meteorological and hydrologic data for use in a near real-time streamflow simulation system. This system is used in the management and operation of reservoirs and other flood-control structures in the West Branch DuPage River watershed in DuPage County, Illinois. The precipitation data are from a network of real-time tipping-bucket rain gages maintained by the USGS and DuPage County. The other meteorological data (air temperature, dewpoint temperature, wind speed, and solar radiation) are collected at the Argonne National Laboratory located in Argonne, Ill. Potential evapotranspiration is computed from the meteorological data. The water-surface elevation (stage) and discharge data for the West Branch DuPage River are collected by the USGS at five streamgages.
This database is updated annually with quality-assured and quality-controlled (QA/QC) data. A version of the database, WBDR13.WDM that contains QA/QC data from January 1, 2007, through September 30, 2013, is described in this report. As part of the QA/QC process, the precipitation datasets in WBDR13.WDM were filled when data were missing and estimated during periods of snowfall at unheated rain gages. The missing data were most often filled with data from a nearby rain gage. Periods of snowfall were flagged "e" in the USGS Annual Water Data Reports by using records from heated gages and air temperature data obtained from the National Climatic Data Center for the nearby weather observation stations. The weather observation station is chosen by the hydrographer working on this record. The missing air temperature, dewpoint temperature, wind speed, and solar radiation data are filled from weather observation stations at St. Charles, Ill., and O'Hare Airport, Chicago, Ill. 


\section{References Cited}

Argonne National Laboratory, 2015, Meteorological data, accessed on April 29, 2015, at URL http://gonzalo.er.anl. gov/ANLMET/.

Bera, Maitreyee, 2014, Watershed Data Management (WDM) database for Salt Creek streamflow simulation, DuPage County, Illinois, water years 2005-11: U.S. Geological Survey Data Series 870, 18 p.

Bera, M., 2017, Watershed Data Management (WDM) Database (WBDR13.WDM) for West Branch DuPage River Streamflow Simulation, DuPage County, Illinois, January 1, 2007, through September 30, 2013: U.S. Geological Survey data release, https://doi.org/10.5066/F71Z42M0.

Bicknell, B.R., Imhoff, J.C., Kittle, J.L., Jr., Jobes, T.H., and Donigian, A.S., Jr., 2000, Hydrological simulation program-FORTRAN (HSPF): User's manual for release 12: U.S. Environmental Protection Agency Research Laboratory, Athens, Ga., [variously paginated].

Flynn, K.M., Hummel, P.R., Lumb, A.M., and Kittle, J.L., Jr., 1995, User's manual for ANNIE, version 2, a computer program for interactive hydrologic data management: U.S. Geological Survey Water-Resources Investigations Report 95-4085, $211 \mathrm{p}$.

Franz, D.D., and Melching, C.S., 1997, Full Equations (FEQ) model for the solution of the full, dynamic equations of motion for one-dimensional unsteady flow in open channels and through control structures: U.S. Geological Survey Water-Resources Investigations Report 96-4240, 207 p., plus appendixes.

Ishii, A.L., Charlton, T.J., Ortel, T.W., and Vonnahme, C.C., 1998, Modeling system for near real-time flood simulation for Salt Creek in Du Page County, Illinois: Subcommittee on Hydrology, Interagency Advisory Committee on Water Data, Proceedings of the First Federal Interagency Hydrologic Modeling Conference, Las Vegas, p. 8.51-8.58.
Kittle, J.L., Jr., Lumb, A.M., Hummel, P.R., Duda, P.B., and Gray, M.H., 1998, A tool for the generation and analysis of model simulation scenarios for watersheds (GenScn): U.S. Geological Survey Water-Resources Investigations Report 98-4134, $152 \mathrm{p}$.

Murphy, E.A., 2005, Comparison of potential evapotranspiration calculated by the LXPET (Lamoreux Potential Evapotranspiration) Program and by the WDMUtil (Watershed Data Management Utility) Program: U.S. Geological Survey Open-File Report 2005-1020, 20 p.

National Centers for Environmental Information, 2017, Climate data online data tools: accessed August 9. 2017, at https://www.ncdc.noaa.gov/cdo-web/datatools.

Ortel, T.W., and Martin, A., Jr., 2010, User's guide for MAGIC-Meteorologic and hydrologic gensen (generate scenarios) input converter: U.S. Geological Survey OpenFile Report 2010-1221, 10 p.

Over, T.M, Price, T.H., and Ishii, A.L., 2010, Development and analysis of a meteorological database, Argonne National Laboratory, Illinois: U.S. Geological Survey OpenFile Report 2010-1220, 67 p.

U.S. Geological Survey, 2015, Automated Data Processing System (ADAPS) database, accessed December 10, 2015, at https://pubs.usgs.gov/of/2003/ofr03123/.

U.S. Geological Survey, 2016, Annual water data reports 2006-2013: Site data sheets, accessed December 19, 2016, at https://wdr.water.usgs.gov/. 



\section{Appendix 1. Dataset Attributes for the WBDR13.WDM Watershed Data Management Database}

More information about these Watershed Data Management database attributes can be found in the following reference:

Flynn, K.M., Hummel, P.R., Lumb, A.M., and Kittle, J.L., Jr., 1995, User's manual for ANNIE, version 2, a computer program for interactive hydrologic data management: U.S. Geological Survey Water-Resources Investigations Report 95-4085, 211 p. (Also available at https://pubs.usgs.gov/wri/1995/4085/report.pdf.) 
Table 1-1. Detail dataset attributes for the WBDR13.WDM Watershed Data Management database.

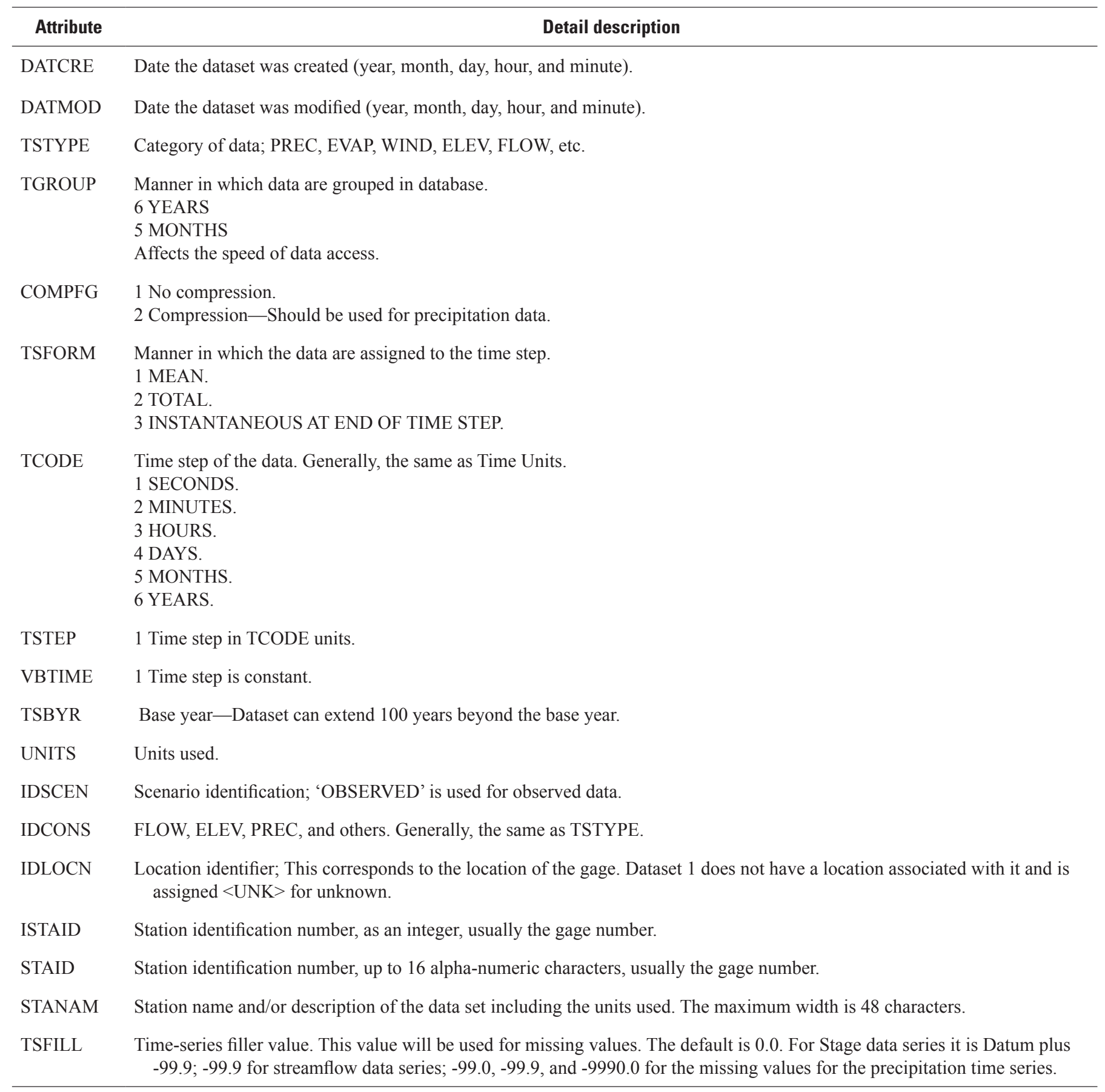




\section{Attributes of DSN 1}

$\begin{array}{ll}\text { DATCRE } & 20090921152328 \\ \text { DATMOD } & 20090921152328 \\ \text { TSTYPE } & \text { ELEV } \\ \text { TGROUP } & 6 \\ \text { COMPFG } & 1 \\ \text { TSFORM } & 1 \\ \text { TCODE } & 3 \\ \text { TSSTEP } & 1 \\ \text { VBTIME } & 1 \\ \text { TSBYR } & 2000 \\ \text { IDSCEN } & \text { OBSERVED } \\ \text { IDCONS } & \text { ELEV } \\ \text { IDLOCN } & <\text { UNK }> \\ \text { STANAM } & \text { dummy datum (600ft) }\end{array}$

\section{Attributes of DSN 107}

$\begin{array}{ll}\text { DATCRE } & 20030407115257 \\ \text { DATMOD } & 20141202030308 \\ \text { TSTYPE } & \text { PREC } \\ \text { TGROUP } & 6 \\ \text { COMPFG } & 1 \\ \text { TSFORM } & 1 \\ \text { TCODE } & 3 \\ \text { TSSTEP } & 1 \\ \text { VBTIME } & 1 \\ \text { TSBYR } & 1990 \\ \text { IDSCEN } & \text { OBSERVED } \\ \text { IDCONS } & \text { PREC } \\ \text { IDLOCN } & \text { ARGONNE } \\ \text { STANAM } & \text { TIPPING BUCKET PREC (.01 in.) at } \\ & \text { ARGONNE } \\ \text { UNITS } & \text { in. } \\ \text { STAID } & \text { ARGONNE }\end{array}$

\section{Attributes of DSN 131}

\begin{tabular}{ll} 
DATCRE & 20090929121726 \\
DATMOD & 20151216155516 \\
TSTYPE & PREC \\
TGROUP & 6 \\
COMPFG & 1 \\
TSFORM & 2 \\
TCODE & 3 \\
TSSTEP & 1 \\
VBTIME & 1 \\
TSBYR & 1990 \\
IDSCEN & OBSERVED \\
IDCONS & PREC \\
IDLOCN & 31 \\
STANAM & NAPERVILLE MUNI BLDG AT NAPER- \\
& \multicolumn{1}{c}{ VILLE, Ill (.01 in.) } \\
UNITS & in. \\
STAID & 414613088091000
\end{tabular}

\section{Attributes of DSN 133}

\begin{tabular}{ll} 
DATCRE & 20090929122247 \\
DATMOD & 20151216155516 \\
TSTYPE & PREC \\
TGROUP & 6 \\
COMPFG & 1 \\
TSFORM & 2 \\
TCODE & 3 \\
TSSTEP & 1 \\
VBTIME & 1 \\
TSBYR & 1990 \\
IDSCEN & OBSERVED \\
IDCONS & PREC \\
IDLOCN & 33 \\
STANAM & WHEATON WATER DEPT AT WHEATON, Ill \\
& \multicolumn{1}{c}{$(.01$ in.) } \\
UNITS & in. \\
STAID & 415300088054600
\end{tabular}




\section{Attributes of DSN 134}

\begin{tabular}{ll} 
DATCRE & 20090929122236 \\
DATMOD & 20151216155516 \\
TSTYPE & PREC \\
TGROUP & 6 \\
COMPFG & 1 \\
TSFORM & 2 \\
TCODE & 3 \\
TSSTEP & 1 \\
VBTIME & 1 \\
TSBYR & 1990 \\
IDSCEN & OBSERVED \\
IDCONS & PREC \\
IDLOCN & 34 \\
STANAM & WHEATON SEWER DEPT. AT WHEATON, Ill \\
& \multicolumn{2}{c}{$(0.01$ in.) } \\
UNITS & in. \\
STAID & 415125088045700
\end{tabular}

\section{Attributes of DSN 140}

\begin{tabular}{ll} 
DATCRE & 20060413161217 \\
DATMOD & 20151216155517 \\
TSTYPE & PREC \\
TGROUP & 6 \\
COMPFG & 1 \\
TSFORM & 2 \\
TCODE & 3 \\
TSSTEP & 1 \\
VBTIME & 1 \\
TSBYR & 1990 \\
IDSCEN & OBSERVED \\
IDCONS & PREC \\
IDLOCN & 40 \\
STANAM & BARTLETT WWTF NEAR BARTLETT, Ill. \\
& \multicolumn{1}{c}{$(.01$ in. $)$} \\
UNITS & in. \\
STAID & 415801088095700
\end{tabular}

\section{Attributes of DSN 144}

\begin{tabular}{ll} 
DATCRE & 20090929121726 \\
DATMOD & 20151216155517 \\
TSTYPE & PREC \\
TGROUP & 6 \\
COMPFG & 1 \\
TSFORM & 2 \\
TCODE & 3 \\
TSSTEP & 1 \\
VBTIME & 1 \\
TSBYR & 1990 \\
IDSCEN & OBSERVED \\
IDCONS & PREC \\
IDLOCN & 44 \\
STANAM & CAROL STREAM WWTF AT CAROL \\
& \multicolumn{2}{c}{ STREAM, Ill (.01 in.) } \\
UNITS & in. \\
STAID & 41523088081500
\end{tabular}

\section{Attributes of DSN 166}

\begin{tabular}{ll} 
DATCRE & 20090929121726 \\
DATMOD & 20151216155517 \\
TSTYPE & PREC \\
TGROUP & 6 \\
COMPFG & 1 \\
TSFORM & 2 \\
TCODE & 3 \\
TSSTEP & 1 \\
VBTIME & 1 \\
TSBYR & 1990 \\
IDSCEN & OBSERVED \\
IDCONS & PREC \\
IDLOCN & 66 \\
STANAM & BLACKWELL FP NEAR WARRENVILLE, \\
& \multicolumn{1}{c}{ Ill (.01 in.) } \\
UNITS & in. \\
STAID & 415037088110600
\end{tabular}


Attributes of DSN 189

$\begin{array}{ll}\text { DATCRE } & 20090929122334 \\ \text { DATMOD } & 20151216155517 \\ \text { TSTYPE } & \text { PREC } \\ \text { TGROUP } & 6 \\ \text { COMPFG } & 1 \\ \text { TSFORM } & 2 \\ \text { TCODE } & 3 \\ \text { TSSTEP } & 1 \\ \text { VBTIME } & 1 \\ \text { TSBYR } & 1990 \\ \text { IDSCEN } & \text { OBSERVED } \\ \text { IDCONS } & \text { PREC } \\ \text { IDLOCN } & 89 \\ \text { STANAM } & \text { KRESS CREEK AT WEST CHICAGO, Ill } \\ & \quad \text { (.01 in.) } \\ \text { UNIT } & \text { in. } \\ \text { STAID } & 05540060\end{array}$

\section{Attributes of DSN 190}

$\begin{array}{ll}\text { DATCRE } & 20090929122334 \\ \text { DATMOD } & 20151216155517 \\ \text { TSTYPE } & \text { PREC } \\ \text { TGROUP } & 6 \\ \text { COMPFG } & 1 \\ \text { TSFORM } & 2 \\ \text { TCODE } & 3 \\ \text { TSSTEP } & 1 \\ \text { VBTIME } & 1 \\ \text { TSBYR } & 1990 \\ \text { IDSCEN } & \text { OBSERVED } \\ \text { IDCONS } & \text { PREC } \\ \text { IDLOCN } & 90 \\ \text { STANAM } & \text { WBDR NEAR NAPERVILLE, Ill (.01 in.) } \\ \text { UNITS } & \text { in. } \\ \text { STAID } & 05540130\end{array}$

\section{Attributes of DSN 207}

\begin{tabular}{ll} 
DATCRE & 20080331131133 \\
DATMOD & 20151215164443 \\
TSTYPE & EVAP \\
TGROUP & 6 \\
COMPFG & 1 \\
TSFORM & 1 \\
TCODE & 3 \\
TSSTEP & 1 \\
VBTIME & 1 \\
TSBYR & 1940 \\
IDSCEN & COMPUTED \\
IDCONS & EVAP \\
IDLOCN & ARGONNE \\
STANAM & COMPUTED EVAP-UNADJUSTED WIND \\
\multicolumn{2}{c}{$(0.001$ in.) } \\
UNITS & in.
\end{tabular}

\section{Attributes of DSN 307}

$\begin{array}{ll}\text { DATCRE } & 20080215125938 \\ \text { DATMOD } & 20151215164443 \\ \text { TSTYPE } & \text { WIND } \\ \text { TGROUP } & 6 \\ \text { COMPFG } & 1 \\ \text { TSFORM } & 2 \\ \text { TCODE } & 3 \\ \text { TSSTEP } & 1 \\ \text { VBTIME } & 1 \\ \text { TSBYR } & 1940 \\ \text { IDSCEN } & \text { OBSERVED } \\ \text { IDCONS } & \text { WIND } \\ \text { IDLOCN } & \text { ARGONNE } \\ \text { STANAM } & \text { UNADJUSTED HOURLY WIND SPEED } \\ & \text { (miles/hr.) at ARGONNE } \\ \text { TSFILL } & -99.9 \\ \text { UNITS } & \text { mi } \\ \text { STAID } & \text { ARGONNE }\end{array}$


Attributes of DSN 310

$\begin{array}{ll}\text { DATCRE } & 2011111713827 \\ \text { DATMOD } & 20151123153620 \\ \text { TSTYPE } & \text { WIND } \\ \text { TGROUP } & 6 \\ \text { COMPFG } & 1 \\ \text { TSFORM } & 1 \\ \text { TCODE } & 3 \\ \text { TSSTEP } & 1 \\ \text { VBTIME } & 1 \\ \text { TSBYR } & 1940 \\ \text { IDSCEN } & \text { FLAG } \\ \text { IDCONS } & \text { WIND } \\ \text { IDLOCN } & \text { ARGONNE } \\ \text { STANAM } & \text { HOURLY WIND FLAG } \\ \text { TSFILL } & -99.9 \\ \text { STAID } & \text { ARGONNE }\end{array}$

Attributes of DSN 407

$\begin{array}{ll}\text { DATCRE } & 20080215113040 \\ \text { DATMOD } & 20151215164443 \\ \text { TSTYPE } & \text { TEMP } \\ \text { TGROUP } & 6 \\ \text { COMPFG } & 1 \\ \text { TSFORM } & 1 \\ \text { TCODE } & 3 \\ \text { TSSTEP } & 1 \\ \text { VBTIME } & 1 \\ \text { TSBYR } & 1940 \\ \text { IDSCEN } & \text { OBSERVED } \\ \text { IDCONS } & \text { TEMP } \\ \text { IDLOCN } & \text { ARGONNE } \\ \text { STANAM } & \text { HOURLY AIR TEMP (deg F) at ARGONNE } \\ \text { TSFILL } & -99.9 \\ \text { UNITS } & \text { deg F } \\ \text { STAID } & \text { ARGONNE }\end{array}$

\section{Attributes of DSN 410}

$\begin{array}{ll}\text { DATCRE } & 20111117113427 \\ \text { DATMOD } & 20151123153620 \\ \text { TSTYPE } & \text { TEMP } \\ \text { TGROUP } & 6 \\ \text { COMPFG } & 1 \\ \text { TSFORM } & 1 \\ \text { TCODE } & 3 \\ \text { TSSTEP } & 1 \\ \text { VBTIME } & 1 \\ \text { TSBYR } & 1940 \\ \text { IDSCEN } & \text { FLAG } \\ \text { IDCONS } & \text { TEMP } \\ \text { IDLOCN } & \text { ARGONNE } \\ \text { STANAM } & \text { HOURLY AIR TEMP FLAG } \\ \text { TSFILL } & -99.9 \\ \text { STAID } & \text { ARGONNE }\end{array}$

\section{Attributes of DSN 507}

\begin{tabular}{ll} 
DATCRE & 20080215122708 \\
DATMOD & 20151215164443 \\
TSTYPE & DEWP \\
TGROUP & 6 \\
COMPFG & 1 \\
TSFORM & 1 \\
TCODE & 3 \\
TSSTEP & 1 \\
VBTIME & 1 \\
TSBYR & 1940 \\
IDSCEN & OBSERVED \\
IDCONS & DEWP \\
IDLOCN & ARGONNE \\
STANAM & HOURLY DEWPOINT TEMP (deg F) at \\
& \multicolumn{1}{c}{ ARGONNE } \\
TSFILL & -99.9 \\
UNITS & deg F \\
STAID & ARGONNE
\end{tabular}


Attributes of DSN 510

$\begin{array}{ll}\text { DATCRE } & 20111117113606 \\ \text { DATMOD } & 20151123153620 \\ \text { TSTYPE } & \text { DEWP } \\ \text { TGROUP } & 6 \\ \text { COMPFG } & 1 \\ \text { TSFORM } & 1 \\ \text { TCODE } & 3 \\ \text { TSSTEP } & 1 \\ \text { VBTIME } & 1 \\ \text { TSBYR } & 1940 \\ \text { IDSCEN } & \text { FLAG } \\ \text { IDCONS } & \text { DEWP } \\ \text { IDLOCN } & \text { ARGONNE } \\ \text { STANAM } & \text { HOURLY DEWPOINT TEMP FLAG } \\ \text { TSFILL } & -99.9 \\ \text { STAID } & \text { ARGONNE }\end{array}$

Attributes of DSN 607

$\begin{array}{ll}\text { DATCRE } & 20080215124924 \\ \text { DATMOD } & 20151215164443 \\ \text { TSTYPE } & \text { SRAD } \\ \text { TGROUP } & 6 \\ \text { COMPFG } & 1 \\ \text { TSFORM } & 2 \\ \text { TCODE } & 3 \\ \text { TSSTEP } & 1 \\ \text { VBTIME } & 1 \\ \text { TSBYR } & 1940 \\ \text { IDSCEN } & \text { OBSERVED } \\ \text { IDCONS } & \text { SRAD } \\ \text { IDLOCN } & \text { ARGONNE } \\ \text { STANAM } & \text { HOURLY SOLAR RADIATION (LANGLEYS) } \\ & \text { at ARGONNE } \\ \text { TSFILL } & -99.9 \\ \text { UNITS } & \text { LANGLEYS } \\ \text { STAID } & \text { ARGONNE }\end{array}$

\section{Attributes of DSN 610}

$\begin{array}{ll}\text { DATCRE } & 20080215143429 \\ \text { DATMOD } & 20151123153620 \\ \text { TSTYPE } & \text { SRAD } \\ \text { TGROUP } & 6 \\ \text { COMPFG } & 1 \\ \text { TSFORM } & 1 \\ \text { TCODE } & 3 \\ \text { TSSTEP } & 1 \\ \text { VBTIME } & 1 \\ \text { TSBYR } & 1940 \\ \text { IDSCEN } & \text { FLAG } \\ \text { IDCONS } & \text { SRAD } \\ \text { IDLOCN } & \text { ARGONNE } \\ \text { STANAM } & \text { HOURLY SOLAR RADIATION FLAG } \\ \text { TSFILL } & -99.9 \\ \text { STAID } & \text { ARGONNE }\end{array}$

\section{Attributes of DSN 801}

\begin{tabular}{ll} 
DATCRE & 20030501144051 \\
DATMOD & 20141202030316 \\
TSTYPE & PREC \\
TGROUP & 6 \\
COMPFG & 1 \\
TSFORM & 2 \\
TCODE & 3 \\
TSSTEP & 1 \\
VBTIME & 1 \\
TSBYR & 1990 \\
IDSCEN & NEXRAD \\
IDCONS & PREC \\
IDLOCN & 801 \\
STANAM & NEXRAD HOURLY AVG FOR WBDR MAIN- \\
& \multicolumn{1}{c}{ STEM (UPPER) INCLUDING TRIB 2 } \\
ISTAID & 801 \\
UNITS & in. \\
TSFILL & -99.9 \\
STAID & 801
\end{tabular}




\section{Attributes of DSN 802}

$\begin{array}{ll}\text { DATCRE } & 20030501144051 \\ \text { DATMOD } & 20141202030316 \\ \text { TSTYPE } & \text { PREC } \\ \text { TGROUP } & 6 \\ \text { COMPFG } & 1 \\ \text { TSFORM } & 2 \\ \text { TCODE } & 3 \\ \text { TSSTEP } & 1 \\ \text { VBTIME } & 1 \\ \text { TSBYR } & 1990 \\ \text { IDSCEN } & \text { NEXRAD } \\ \text { IDCONS } & \text { PREC } \\ \text { IDLOCN } & 802 \\ \text { STANAM } & \text { NEXRAD HOURLY AVG FOR WBDR TRIB1 } \\ \text { ISTAID } & 802 \\ \text { UNITS } & \text { in. } \\ \text { TSFILL } & -99.9 \\ \text { STAID } & 802\end{array}$

\section{Attributes of DSN 803}

$\begin{array}{ll}\text { DATCRE } & 20030501144051 \\ \text { DATMOD } & 20141202030316 \\ \text { TSTYPE } & \text { PREC } \\ \text { TGROUP } & 6 \\ \text { COMPFG } & 1 \\ \text { TSFORM } & 2 \\ \text { TCODE } & 3 \\ \text { TSSTEP } & 1 \\ \text { VBTIME } & 1 \\ \text { TSBYR } & 1990 \\ \text { IDSCEN } & \text { NEXRAD } \\ \text { IDCONS } & \text { PREC } \\ \text { IDLOCN } & 803 \\ \text { STANAM } & \text { NEXRAD HOURLY AVG FOR WBDR TRIB } 4 \\ \text { ISTAID } & 803 \\ \text { UNITS } & \text { in. } \\ \text { TSFILL } & -99.9 \\ \text { STAID } & 803\end{array}$

\section{Attributes of DSN 804}

\begin{tabular}{ll} 
DATCRE & 20030501144051 \\
DATMOD & 20141202030316 \\
TSTYPE & PREC \\
TGROUP & 6 \\
COMPFG & 1 \\
TSFORM & 2 \\
TCODE & 3 \\
TSSTEP & 1 \\
VBTIME & 1 \\
TSBYR & 1990 \\
IDSCEN & NEXRAD \\
IDCONS & PREC \\
IDLOCN & 804 \\
STANAM & NEXRAD HOURLY AVG FOR WBDR \\
& \multicolumn{1}{c}{ MAINSTEM (MID) } \\
ISTAID & 804 \\
UNITS & in. \\
TSFILL & -99.9 \\
STAID & 804
\end{tabular}

\section{Attributes of DSN 805}

$\begin{array}{ll}\text { DATCRE } & 20030501144051 \\ \text { DATMOD } & 20141202030316 \\ \text { TSTYPE } & \text { PREC } \\ \text { TGROUP } & 6 \\ \text { COMPFG } & 1 \\ \text { TSFORM } & 2 \\ \text { TCODE } & 3 \\ \text { TSSTEP } & 1 \\ \text { VBTIME } & 1 \\ \text { TSBYR } & 1990 \\ \text { IDSCEN } & \text { NEXRAD } \\ \text { IDCONS } & \text { PREC } \\ \text { IDLOCN } & 805 \\ \text { STANAM } & \text { NEXRAD HOURLY AVG FOR KLEIN CREEK } \\ \text { ISTAID } & 805 \\ \text { UNITS } & \text { in. } \\ \text { TSFILL } & -99.9 \\ \text { STAID } & 805\end{array}$


Attributes of DSN 806

\begin{tabular}{ll} 
DATCRE & 20030501144051 \\
DATMOD & 20141202030316 \\
TSTYPE & PREC \\
TGROUP & 6 \\
COMPFG & 1 \\
TSFORM & 2 \\
TCODE & 3 \\
TSSTEP & 1 \\
VBTIME & 1 \\
TSBYR & 1990 \\
IDSCEN & NEXRAD \\
IDCONS & PREC \\
IDLOCN & 806 \\
STANAM & NEXRAD HOURLY AVG FOR WINFIELD \\
& \multicolumn{1}{c}{ CREEK } \\
ISTAID & 806 \\
UNITS & in. \\
TSFILL & -99.9 \\
STAID & 806
\end{tabular}

\section{Attributes of DSN 807}

$\begin{array}{ll}\text { DATCRE } & 20030501144051 \\ \text { DATMOD } & 20141202030316 \\ \text { TSTYPE } & \text { PREC } \\ \text { TGROUP } & 6 \\ \text { COMPFG } & 1 \\ \text { TSFORM } & 2 \\ \text { TCODE } & 3 \\ \text { TSSTEP } & 1 \\ \text { VBTIME } & 1 \\ \text { TSBYR } & 1990 \\ \text { IDSCEN } & \text { NEXRAD } \\ \text { IDCONS } & \text { PREC } \\ \text { IDLOCN } & 807 \\ \text { STANAM } & \text { NEXRAD HOURLY AVG FOR KRESS CREEK } \\ \text { ISTAID } & 807 \\ \text { UNITS } & \text { in. } \\ \text { TSFILL } & -99.9 \\ \text { STAID } & 807\end{array}$

\section{Attributes of DSN 808}

$\begin{array}{ll}\text { DATCRE } & 20030501144051 \\ \text { DATMOD } & 20141202030316 \\ \text { TSTYPE } & \text { PREC } \\ \text { TGROUP } & 6 \\ \text { COMPFG } & 1 \\ \text { TSFORM } & 2 \\ \text { TCODE } & 3 \\ \text { TSSTEP } & 1 \\ \text { VBTIME } & 1 \\ \text { TSBYR } & 1990 \\ \text { IDSCEN } & \text { NEXRAD } \\ \text { IDCONS } & \text { PREC } \\ \text { IDLOCN } & 808 \\ \text { STANAM } & \text { NEXRAD HOURLY AVG FOR SPRINGBROOK 1 } \\ \text { ISTAID } & 808 \\ \text { STAID } & 808 \\ \text { UNITS } & \text { in. } \\ \text { TSFILL } & -99.9\end{array}$

\section{Attributes of DSN 809}

$\begin{array}{ll}\text { DATCRE } & 20030501144051 \\ \text { DATMOD } & 20141202030316 \\ \text { TSTYPE } & \text { PREC } \\ \text { TGROUP } & 6 \\ \text { COMPFG } & 1 \\ \text { TSFORM } & 2 \\ \text { TCODE } & 3 \\ \text { TSSTEP } & 1 \\ \text { VBTIME } & 1 \\ \text { TSBYR } & 1990 \\ \text { IDSCEN } & \text { NEXRAD } \\ \text { IDCONS } & \text { PREC } \\ \text { IDLOCN } & 809 \\ \text { STANAM } & \text { NEXRAD HOURLY AVG FOR FERRY CREEK } \\ \text { ISTAID } & 809 \\ \text { UNITS } & \text { in. } \\ \text { TSFILL } & -99.9 \\ \text { STAID } & 809\end{array}$


Attributes of DSN 810

$\begin{array}{ll}\text { DATCRE } & 20030501144051 \\ \text { DATMOD } & 20141202030316 \\ \text { TSTYPE } & \text { PREC } \\ \text { TGROUP } & 6 \\ \text { COMPFG } & 1 \\ \text { TSFORM } & 2 \\ \text { TCODE } & 3 \\ \text { TSSTEP } & 1 \\ \text { VBTIME } & 1 \\ \text { TSBYR } & 1990 \\ \text { IDSCEN } & \text { NEXRAD } \\ \text { IDCONS } & \text { PREC } \\ \text { IDLOCN } & 810 \\ \text { STANAM } & \text { NEXRAD HOURLY AVG FOR STEEPLE RUN } \\ \text { ISTAID } & 810 \\ \text { UNITS } & \text { in. } \\ \text { TSFILL } & -99.9 \\ \text { STAID } & 810\end{array}$

\section{Attributes of DSN 811}

\begin{tabular}{ll} 
DATCRE & 20030501144051 \\
DATMOD & 20141202030316 \\
TSTYPE & PREC \\
TGROUP & 6 \\
COMPFG & 1 \\
TSFORM & 2 \\
TCODE & 3 \\
TSSTEP & 1 \\
VBTIME & 1 \\
TSBYR & 1990 \\
IDSCEN & NEXRAD \\
IDCONS & PREC \\
IDLOCN & 811 \\
STANAM & NEXRAD HOURLY AVG FOR WBDR MAIN- \\
& \multicolumn{1}{c}{ STEM (LOWER) INCLUDING CRESS } \\
& CREEK \\
ISTAID & 811 \\
UNITS & in. \\
TSFILL & -99.9 \\
STAID & 811
\end{tabular}

\section{Attributes of DSN 2060}

$\begin{array}{ll}\text { DATCRE } & 20090930093045 \\ \text { DATMOD } & 20151218142539 \\ \text { TSTYPE } & \text { FLOW } \\ \text { TGROUP } & 6 \\ \text { COMPFG } & 1 \\ \text { TSFORM } & 3 \\ \text { TCODE } & 3 \\ \text { TSSTEP } & 1 \\ \text { VBTIME } & 1 \\ \text { TSBYR } & 1990 \\ \text { IDSCEN } & \text { OBSERVED } \\ \text { IDCONS } & \text { FLOW } \\ \text { IDLOCN } & 05540060 \\ \text { STANAM } & \text { KRESS CREEK AT WEST CHICAGO, Ill (cfs) } \\ \text { STAID } & 05540060 \\ \text { UNITS } & \mathrm{ft}^{3} / \mathrm{s} .\end{array}$

Attributes of DSN 2130

$\begin{array}{ll}\text { DATCRE } & 20090930093033 \\ \text { DATMOD } & 20151218142539 \\ \text { TSTYPE } & \text { FLOW } \\ \text { TGROUP } & 6 \\ \text { COMPFG } & 1 \\ \text { TSFORM } & 3 \\ \text { TCODE } & 3 \\ \text { TSSTEP } & 1 \\ \text { VBTIME } & 1 \\ \text { TSBYR } & 1990 \\ \text { IDSCEN } & \text { OBSERVED } \\ \text { IDCONS } & \text { FLOW } \\ \text { IDLOCN } & 05540130 \\ \text { STANAM } & \text { WBDR NEAR NAPERVILLE, Ill (cfs) } \\ \text { STAID } & 05540130 \\ \text { UNITS } & \mathrm{ft}^{3} / \mathrm{s} .\end{array}$


Attributes of DSN 2750

\begin{tabular}{ll} 
DATCRE & 20090930093108 \\
DATMOD & 20151218142539 \\
TSTYPE & FLOW \\
TGROUP & 6 \\
COMPFG & 1 \\
TSFORM & 3 \\
TCODE & 3 \\
TSSTEP & 1 \\
VBTIME & 1 \\
TSBYR & 1990 \\
IDSCEN & OBSERVED \\
IDCONS & FLOW \\
IDLOCN & 05540275 \\
STANAM & SPRINGBROOK AT $87^{\text {TH }}$ ST. NEAR NAPER- \\
\multicolumn{1}{c}{ VILLE, Ill (cfs) } \\
STAID & 05540275 \\
UNITS & ft 3 s.
\end{tabular}

\section{Attributes of DSN 2990}

$\begin{array}{ll}\text { DATCRE } & 20090930093024 \\ \text { DATMOD } & 20151218142539 \\ \text { TSTYPE } & \text { FLOW } \\ \text { TGROUP } & 6 \\ \text { COMPFG } & 1 \\ \text { TSFORM } & 3 \\ \text { TCODE } & 3 \\ \text { TSSTEP } & 1 \\ \text { VBTIME } & 1 \\ \text { TSBYR } & 1990 \\ \text { IDSCEN } & \text { OBSERVED } \\ \text { IDCONS } & \text { FLOW } \\ \text { IDLOCN } & 05539900 \\ \text { STANAM } & \text { WBDR NEAR WEST CHICAGO, Ill (cfs) } \\ \text { STAID } & 05539900 \\ \text { UNITS } & \mathrm{ft}^{3} / \mathrm{s} .\end{array}$

\section{Attributes of DSN 2950}

$\begin{array}{ll}\text { DATCRE } & 20090930093100 \\ \text { DATMOD } & 20151218142539 \\ \text { TSTYPE } & \text { FLOW } \\ \text { TGROUP } & 6 \\ \text { COMPFG } & 1 \\ \text { TSFORM } & 3 \\ \text { TCODE } & 3 \\ \text { TSSTEP } & 1 \\ \text { VBTIME } & 1 \\ \text { TSBYR } & 1990 \\ \text { IDSCEN } & \text { OBSERVED } \\ \text { IDCONS } & \text { FLOW } \\ \text { IDLOCN } & 05540095 \\ \text { STANAM } & \text { WBDR NEAR WARRENVILLE, Ill (cfs) } \\ \text { STAID } & 05540095 \\ \text { UNITS } & \mathrm{ft}^{3} / \mathrm{s} .\end{array}$




\section{Attributes of DSN 4031}

$\begin{array}{ll}\text { DATCRE } & 20100219143213 \\ \text { DATMOD } & 20141202030311 \\ \text { TSTYPE } & \text { ELEV } \\ \text { TGROUP } & 6 \\ \text { COMPFG } & 1 \\ \text { TSFORM } & 1 \\ \text { TCODE } & 3 \\ \text { TSSTEP } & 1 \\ \text { VBTIME } & 1 \\ \text { TSBYR } & 2000 \\ \text { IDSCEN } & \text { OBSERVED } \\ \text { IDCONS } & \text { ELEV } \\ \text { IDLOCN } & \text { D31 } \\ \text { STANAM } & \text { FAWELL DAM IN WBDR WATERSHED (ft.) } \\ \text { STAID } & \text { D31 } \\ \text { UNITS: } & \mathrm{ft}\end{array}$

\section{Attributes of DSN 4060}

$\begin{array}{ll}\text { DATCRE } & 20100219143213 \\ \text { DATMOD } & 20151218142539 \\ \text { TSTYPE } & \text { ELEV } \\ \text { TGROUP } & 6 \\ \text { COMPFG } & 2 \\ \text { TSFORM } & 3 \\ \text { TCODE } & 3 \\ \text { TSSTEP } & 1 \\ \text { VBTIME } & 1 \\ \text { TSBYR } & 2000 \\ \text { IDSCEN } & \text { OBSERVED } \\ \text { IDCONS } & \text { ELEV } \\ \text { IDLOCN } & 05540060 \\ \text { STANAM } & \text { KRESS CREEK AT WEST CHICAGO, Ill (ft.) } \\ \text { STAID } & 05540060 \\ \text { UNITS } & \text { ft. }\end{array}$

\section{Attributes of DSN 4130}

$\begin{array}{ll}\text { DATCRE } & 20090930093129 \\ \text { DATMOD } & 20151218142538 \\ \text { TSTYPE } & \text { ELEV } \\ \text { TGROUP } & 6 \\ \text { COMPFG } & 2 \\ \text { TSFORM } & 3 \\ \text { TCODE } & 3 \\ \text { TSSTEP } & 1 \\ \text { VBTIME } & 1 \\ \text { TSBYR } & 1990 \\ \text { IDSCEN } & \text { OBSERVED } \\ \text { IDCONS } & \text { ELEV } \\ \text { IDLOCN } & 05540130 \\ \text { STANAM } & \text { WBDR NEAR NAPERVILLE (ft.) } \\ \text { STAID } & 05540130 \\ \text { UNITS } & \mathrm{ft} .\end{array}$

\section{Attributes of DSN 4750}

$\begin{array}{ll}\text { DATCRE } & 20090930093204 \\ \text { DATMOD } & 20151218142539 \\ \text { TSTYPE } & \text { ELEV } \\ \text { TGROUP } & 6 \\ \text { COMPFG } & 2 \\ \text { TSFORM } & 3 \\ \text { TCODE } & 3 \\ \text { TSSTEP } & 1 \\ \text { VBTIME } & 1 \\ \text { TSBYR } & 1990 \\ \text { IDSCEN } & \text { OBSERVED } \\ \text { IDCONS } & \text { ELEV } \\ \text { IDLOCN } & 05540275 \\ \text { STANAM } & \text { SPRING BROOK AT } 87^{\text {TH }} \text { ST (ft.) } \\ \text { STAID } & 05540275 \\ \text { UNITS } & \text { ft. }\end{array}$


Attributes of DSN 4950

$\begin{array}{ll}\text { DATCRE } & 20090930093154 \\ \text { DATMOD } & 20151218151619 \\ \text { TSTYPE } & \text { ELEV } \\ \text { TGROUP } & 6 \\ \text { COMPFG } & 2 \\ \text { TSFORM } & 3 \\ \text { TCODE } & 3 \\ \text { TSSTEP } & 1 \\ \text { VBTIME } & 1 \\ \text { TSBYR } & 1990 \\ \text { IDSCEN } & \text { OBSERVED } \\ \text { IDCONS } & \text { ELEV } \\ \text { IDLOCN } & 05540095 \\ \text { STANAM } & \text { WARRENVILLE, Ill (ft.) } \\ \text { STAID } & 05540095 \\ \text { UNITS } & \text { ft. }\end{array}$

\section{Attributes of DSN 4990}

$\begin{array}{ll}\text { DATCRE } & 20090930093121 \\ \text { DATMOD } & 20151218142538 \\ \text { TSTYPE } & \text { ELEV } \\ \text { TGROUP } & 6 \\ \text { COMPFG } & 2 \\ \text { TSFORM } & 3 \\ \text { TCODE } & 3 \\ \text { TSSTEP } & 1 \\ \text { VBTIME } & 1 \\ \text { TSBYR } & 1990 \\ \text { IDSCEN } & \text { OBSERVED } \\ \text { IDCONS } & \text { ELEV } \\ \text { IDLOCN } & 05539900 \\ \text { STANAM } & \text { WBDR NEAR WEST CHICAGO, Ill (ft.) } \\ \text { STAID } & 05539900 \\ \text { UNITS } & \text { ft. }\end{array}$

\section{Attributes of DSN 6207}

$\begin{array}{ll}\text { DATCRE } & 20130215131607 \\ \text { DATMOD } & 20130215132412 \\ \text { TSTYPE } & \text { PERO } \\ \text { STAID } & 05551700 \\ \text { STANAM } & \text { FLAT GRASS RUNOFF (IN/HOUR*SQ MI) } \\ \text { TCODE } & 3 \\ \text { TGROUP } & 6 \\ \text { TSFORM } & 2 \\ \text { VBTIME } & 1 \\ \text { COMPFG } & 1 \\ \text { TSSTEP } & 1 \\ \text { TSBYR } & 2000 \\ \text { IDSCEN } & \text { COMPUTED } \\ \text { IDLOCN } & \text { GENERIC } \\ \text { IDCONS } & \text { ERO } \\ \text { TSFILL } & -99.9 \\ \text { ISTAID } & 5551700\end{array}$

\section{Attributes of DSN 6307}

$\begin{array}{ll}\text { DATCRE } & 20130215131736 \\ \text { DATMOD } & 20130215132412 \\ \text { TSTYPE } & \text { PERO } \\ \text { STAID } & 05551700 \\ \text { STANAM } & \text { MODERATE GRASS RUNOFF (IN/HOUR*SQ MI) } \\ \text { TCODE } & 3 \\ \text { TGROU } & 6 \\ \text { TSFORM } & 2 \\ \text { VBTIME } & 1 \\ \text { COMPFG } & 1 \\ \text { TSSTEP } & 1 \\ \text { TSBYR } & 2000 \\ \text { IDSCEN } & \text { COMPUTED } \\ \text { IDLOCN } & \text { GENERIC } \\ \text { IDCONS } & \text { PERO } \\ \text { TSFILL } & -99.9 \\ \text { ISTAID } & 5551700\end{array}$


Attributes of DSN 6407

$\begin{array}{ll}\text { DATCRE } & 20130215131501 \\ \text { DATMOD } & 20130215132412 \\ \text { TSTYPE } & \text { PERO } \\ \text { STAID } & 05551700 \\ \text { STANAM } & \text { STEEP GRASS RUNOFF (IN/HOUR*SQ MI) } \\ \text { TCODE } & 3 \\ \text { TGROUP } & 6 \\ \text { TSFORM } & 2 \\ \text { VBTIME } & 1 \\ \text { COMPFG } & 1 \\ \text { TSSTEP } & 1 \\ \text { TSBYR } & 2000 \\ \text { IDSCEN } & \text { COMPUTED } \\ \text { IDLOCN } & \text { GENERIC } \\ \text { IDCONS } & \text { PERO } \\ \text { TSFILL } & -99.9\end{array}$

\section{Attributes of DSN 6607}

$\begin{array}{ll}\text { DATCRE } & 20130215131607 \\ \text { DATMOD } & 20130215132412 \\ \text { TSTYPE } & \text { PERO } \\ \text { STAID } & 05551700 \\ \text { STANAM } & \text { AGRICULTURE RUNOFF (IN/HOUR*SQ MI) } \\ \text { TCODE } & 3 \\ \text { TGROUP } & 6 \\ \text { TSFORM } & 2 \\ \text { VBTIME } & 1 \\ \text { COMPFG } & 1 \\ \text { TSSTEP } & 1 \\ \text { TSBYR } & 2000 \\ \text { IDSCEN } & \text { COMPUTED } \\ \text { IDLOCN } & \text { GENERIC } \\ \text { IDCONS } & \text { PERO } \\ \text { TSFILL } & -99.9\end{array}$

\section{Attributes of DSN 6507}

$\begin{array}{ll}\text { DATCRE } & 20130215131325 \\ \text { DATMOD } & 20130215132412 \\ \text { TSTYPE } & \text { PERO } \\ \text { STAID } & 05551700 \\ \text { STANAM } & \text { FOREST RUNOFF (IN/HOUR*SQ MI) } \\ \text { TCODE } & 3 \\ \text { TGROUP } & 6 \\ \text { TSFORM } & 2 \\ \text { VBTIME } & 1 \\ \text { COMPFG } & 1 \\ \text { TSSTEP } & 1 \\ \text { TSBYR } & 2000 \\ \text { IDSCEN } & \text { COMPUTED } \\ \text { IDLOCN } & \text { GENERIC } \\ \text { IDCONS } & \text { PERO } \\ \text { TSFILL } & -99.9\end{array}$

\section{Attributes of DSN 7012}

$\begin{array}{ll}\text { DATCRE } & 20130215133257 \\ \text { DATMOD } & 20130215133358 \\ \text { TSTYPE } & \text { SURO } \\ \text { STAID } & 05551700 \\ \text { STANAM } & \text { SURFACE OUTFLOW (IN/HR*SQ MI) } \\ \text { TCODE } & 3 \\ \text { TGROUP } & 6 \\ \text { TSFORM } & 2 \\ \text { VBTIME } & 1 \\ \text { COMPFG } & 1 \\ \text { TSSTEP } & 1 \\ \text { TSBYR } & 2000 \\ \text { IDLOCN } & \text { GENERIC } \\ \text { IDSCEN } & \text { COMPUTED } \\ \text { IDCONS } & \text { SURO } \\ \text { TSFILL } & -99.9\end{array}$




\section{Attributes of DSN 7013}

$\begin{array}{ll}\text { DATCRE } & 20130215133257 \\ \text { DATMOD } & 20130215133358 \\ \text { TSTYPE } & \text { IFWO } \\ \text { STAID } & 05551700 \\ \text { STANAM } & \text { INTERFLOW OUTFLOW (IN/HR *SQ MI) } \\ \text { TCODE } & 3 \\ \text { TGROUP } & 6 \\ \text { TSFORM } & 2 \\ \text { VBTIME } & 1 \\ \text { COMPFG } & 1 \\ \text { TSSTEP } & 1 \\ \text { TSBYR } & 2000 \\ \text { IDLOCN } & \text { GENERIC } \\ \text { IDSCEN } & \text { COMPUTED } \\ \text { IDCONS } & \text { IFWO } \\ \text { TSFILL } & -99.9\end{array}$

Attributes of DSN 7014

$\begin{array}{ll}\text { DATCRE } & 20130215134119 \\ \text { DATMOD } & 20130215134626 \\ \text { TSTYPE } & \text { PET } \\ \text { STAID } & 05551700 \\ \text { STANAM } & \text { PET (IN/DAY*SQ MI) } \\ \text { TCODE } & 4 \\ \text { TGROUP } & 6 \\ \text { TSFORM } & 2 \\ \text { VBTIME } & 1 \\ \text { COMPFG } & 1 \\ \text { TSSTEP } & 1 \\ \text { TSBYR } & 2000 \\ \text { IDLOCN } & \text { GENERIC } \\ \text { IDSCEN } & \text { COMPUTED } \\ \text { IDCONS } & \text { PET } \\ \text { TSFILL } & -99.9\end{array}$

\section{Attributes of DSN 7015}

$\begin{array}{ll}\text { DATCRE } & 20130215135259 \\ \text { DATMOD } & 20130215135509 \\ \text { TSTYPE } & \text { TAET } \\ \text { STAID } & 05551700 \\ \text { STANAM } & \text { SIMULATED ET (IN/DAY*SQ MI) } \\ \text { TCODE } & 4 \\ \text { TGROUP } & 6 \\ \text { TSFORM } & 2 \\ \text { VBTIME } & 1 \\ \text { COMPFG } & 1 \\ \text { TSSTEP } & 1 \\ \text { TSBYR } & 2000 \\ \text { IDLOCN } & \text { GENERIC } \\ \text { IDSCEN } & \text { COMPUTED } \\ \text { IDCONS } & \text { TAET } \\ \text { TSFILL } & -99.9\end{array}$

Attributes of DSN 7016

$\begin{array}{ll}\text { DATCRE } & 20130215134924 \\ \text { DATMOD } & 20130215135202 \\ \text { TSTYPE } & \text { UZS } \\ \text { STAID } & 05551700 \\ \text { STANAM } & \text { UPPER ZONE STORAGE (IN*SQ MI) } \\ \text { TCODE } & 4 \\ \text { TGROUP } & 6 \\ \text { TSFORM } & 1 \\ \text { VBTIME } & 1 \\ \text { COMPFG } & 1 \\ \text { TSSTEP } & 1 \\ \text { TSBYR } & 2000 \\ \text { IDLOCN } & \text { GENERIC } \\ \text { IDSCEN } & \text { COMPUTED } \\ \text { IDCONS } & \text { UZS } \\ \text { TSFILL } & -99.9\end{array}$




\section{Attributes of DSN 7017}

$\begin{array}{ll}\text { DATCRE } & \text { 20130215135702 } \\ \text { DATMOD } & 20130215135737 \\ \text { TSTYPE } & \text { LZS } \\ \text { STAID } & 05551700 \\ \text { STANAM } & \text { LOWER ZONE STORAGE (IN*SQ MI) } \\ \text { TCODE } & 4 \\ \text { TGROUP } & 6 \\ \text { TSFORM } & 1 \\ \text { VBTIME } & 1 \\ \text { COMPFG } & 1 \\ \text { TSSTEP } & 1 \\ \text { TSBYR } & 2000 \\ \text { IDLOCN } & \text { GENERIC } \\ \text { IDSCEN } & \text { COMPUTED } \\ \text { IDCONS } & \text { LZS } \\ \text { TSFILL } & -99.9\end{array}$

Attributes of DSN 7018

$\begin{array}{ll}\text { DATCRE } & 20130215133257 \\ \text { DATMOD } & 20130215133358 \\ \text { TSTYPE } & \text { AGWS } \\ \text { STAID } & 05551700 \\ \text { STANAM } & \text { GW STORAGE AT START (in.) } \\ \text { TCODE } & 3 \\ \text { TGROUP } & 6 \\ \text { TSFORM } & 2 \\ \text { VBTIME } & 1 \\ \text { COMPFG } & 1 \\ \text { TSSTEP } & 1 \\ \text { TSBYR } & 2000 \\ \text { IDLOCN } & \text { GENERIC } \\ \text { IDSCEN } & \text { COMPUTED } \\ \text { DCONS : } & \text { AGWS }\end{array}$

\section{Attributes of DSN 7119}

$\begin{array}{ll}\text { DATCRE } & 20130215132902 \\ \text { DATMOD } & 20130215133142 \\ \text { TSTYPE } & \text { SNOW } \\ \text { STAID } & 05551700 \\ \text { STANAM } & \text { SIMULATED SNOW DEPTH (in.) } \\ \text { TCODE } & 3 \\ \text { TGROUP } & 6 \\ \text { TSFORM } & 1 \\ \text { VBTIME } & 1 \\ \text { COMPFG } & 1 \\ \text { TSSTEP } & 1 \\ \text { TSBYR } & 2000 \\ \text { IDLOCN } & \text { GENERIC } \\ \text { IDSCEN } & \text { COMPUTED } \\ \text { IDCONS } & \text { SNOW } \\ \text { TSFILL } & -99.9\end{array}$

\section{Attributes of DSN 6107}

$\begin{array}{ll}\text { DATCRE } & 20130215131736 \\ \text { DATMOD } & 20130215132412 \\ \text { TSTYPE } & \text { ISUR } \\ \text { STAID } & 05551700 \\ \text { STANAM } & \text { IMPERVIOUS RUNOFF } \\ \text { TCODE } & 3 \\ \text { TGROUP } & 6 \\ \text { TSFORM } & 2 \\ \text { VBTIME } & 1 \\ \text { COMPFG } & 1 \\ \text { TSSTEP } & 1 \\ \text { TSBYR } & 2000 \\ \text { IDSCEN } & \text { COMPUTED } \\ \text { IDLOCN } & \text { GENERIC } \\ \text { IDCONS } & \text { ISUR } \\ \text { ISTAID } & 5551700 \\ \text { TSFILL } & -99.9\end{array}$


Appendix 2. Descriptions of Missing Data Periods and Estimated Days in the Precipitation, Stage, and Discharge Data in the WBDR13.WDM Watershed Data Management Database 
Table 2-1. Missing data periods for real-time network of rain gages along West Branch DuPage River in and near DuPage County, Illinois, January 1, 2007, through September 30, 2013, in the WBDR13.WDM Watershed Data Management database.

[For more details, consult the corresponding annual U.S. Geological Survey (USGS) water data report at https://wdr.water.usgs.gov; site numbers correspond to figure 1; DSN, dataset number; Ill., Illinois; WWTF, wastewater treatment facility; Do., ditto]

\begin{tabular}{|c|c|}
\hline Station data used to fill missing period (site number) & $\begin{array}{l}\text { Missing data period } \\
\text { (month/day/year) }\end{array}$ \\
\hline \multicolumn{2}{|c|}{ Naperville Municipal Building at Naperville, III. (Site 31; DSN 131) } \\
\hline Blackwell Forest Preserve near Warrenville, Ill. (Site 66) & $01 / 26 / 2012$ \\
\hline \multicolumn{2}{|c|}{ Wheaton Water Department at Wheaton, III. (Site 33; DSN 133) } \\
\hline \multirow[t]{4}{*}{ Wheaton Sewer Department at Wheaton, Ill. (Site 34) } & $03 / 14 / 2008-03 / 20 / 2008$ \\
\hline & $06 / 15 / 2008-06 / 17 / 2008$ \\
\hline & $11 / 04 / 2010-12 / 07 / 2010$ \\
\hline & 05/08/2012-08/01/2012 \\
\hline \multicolumn{2}{|c|}{ Wheaton Sewer Department at Wheaton, III. (Site 34; DSN 134) } \\
\hline \multirow[t]{11}{*}{ Wheaton Water Department at Wheaton, Ill. (Site 33) } & $03 / 15 / 2009-03 / 17 / 2009$ \\
\hline & 04/16/2009-04/18/2009 \\
\hline & $05 / 19 / 2009-05 / 23 / 2009$ \\
\hline & $06 / 23 / 2009-06 / 25 / 09$ \\
\hline & 07/01/2009-07/03/09 \\
\hline & 07/21/2009-08/16/09 \\
\hline & 08/18/2009-08/19/09 \\
\hline & 08/21/2009-08/24/09 \\
\hline & 08/26/2009-08/27/09 \\
\hline & 08/29/2009-11/23/09 \\
\hline & $07 / 21 / 2013-08 / 22 / 13$ \\
\hline \multicolumn{2}{|c|}{ Bartlett WWTF near Bartlett, III. (Site 40; DSN 140) } \\
\hline Bloomingdale Lift Station at Bloomingdale, Ill. (Site 23) & $08 / 25 / 2007-10 / 01 / 2007$ \\
\hline Spring Creek Reservoir near Bloomingdale, Ill. (Site 50) & $10 / 02 / 2007-11 / 04 / 2007$ \\
\hline Do. & $12 / 01 / 2009-12 / 23 / 2010$ \\
\hline Bloomingdale Lift Station at Bloomingdale, Ill. (Site 23) & $12 / 24 / 2009-12 / 25 / 2009$ \\
\hline Spring Creek Reservoir near Bloomingdale, Ill. (Site 50) & $12 / 26 / 2009-02 / 22 / 2010$ \\
\hline Do. & $05 / 21 / 2011-06 / 07 / 2011$ \\
\hline Wood Dale WWTF at Wood Dale, Ill. (Site 29) & 08/19/2011-09/08/2011 \\
\hline Spring Creek Reservoir near Bloomingdale, Ill. (Site 50) & 09/09/2011-09/26/2011 \\
\hline Do. & $11 / 09 / 2011-12 / 02 / 2011$ \\
\hline \multicolumn{2}{|c|}{ Carol Stream WWTF at Carol Stream, III. (Site 44; DSN 144) } \\
\hline \multirow[t]{4}{*}{ Wheaton Water Department at Wheaton, Ill. (Site 33) } & 08/05/2009-08/09/2009 \\
\hline & 09/11/2009-09/13/2009 \\
\hline & $10 / 01 / 2009-11 / 23 / 2009$ \\
\hline & $11 / 09 / 2011-01 / 19 / 2012$ \\
\hline
\end{tabular}


Table 2-1. Missing data periods for real-time network of rain gages along West Branch DuPage River in and near DuPage County, Illinois, January 1, 2007, through September 30, 2013, in the WBDR13.WDM Watershed Data Management database.-Continued

[For more details, consult the corresponding annual U.S. Geological Survey (USGS) water data report at https://wdr.water.usgs.gov; site numbers correspond to figure 1; DSN, dataset number; Ill., Illinois; WWTF, wastewater treatment facility; Do., ditto]

\begin{tabular}{|c|c|}
\hline Station data used to fill missing period (site number) & $\begin{array}{l}\text { Missing data period } \\
\text { (month/day/year) }\end{array}$ \\
\hline \multicolumn{2}{|c|}{ Blackwell Forest Preserve near Warrenville, III. (Site 66; DSN 166) } \\
\hline Wheaton Sewer Department at Wheaton, Ill. (Site 34) & $08 / 24 / 2007-11 / 17 / 2007$ \\
\hline Do. & $03 / 14 / 2008-03 / 20 / 2008$ \\
\hline Wheaton Water Department at Wheaton, Ill. (Site 33) & 08/01/2009-11/23/2009 \\
\hline Wheaton Sewer Department at Wheaton, Ill. (Site 34) & $10 / 24 / 2010-08 / 18 / 2011$ \\
\hline Do. & $12 / 21 / 2012-01 / 27 / 2013$ \\
\hline Do. & $08 / 28 / 2013-09 / 30 / 2013$ \\
\hline \multicolumn{2}{|c|}{ Kress Creek at West Chicago, III. (Site 89; DSN 189) } \\
\hline Blackwell Forest Preserve near Warrenville, Ill. (Site 66) & 01/01/2009-01/02/2009 \\
\hline Wheaton Sewer Department at (Site 34) & $01 / 01 / 2011-04 / 05 / 2011$ \\
\hline Do. & 04/28/2011-09/30/2011 \\
\hline Do. & $10 / 01 / 2011-02 / 21 / 2012$ \\
\hline Do. & $06 / 19 / 2012$ \\
\hline \multicolumn{2}{|c|}{ West Branch DuPage River near Naperville, III. (USGS gage 05540130; DSN 190) } \\
\hline \multirow[t]{21}{*}{ Naperville Municipal Building. at Naperville, Ill. (Site 31) } & $02 / 03 / 2008-02 / 06 / 2008$ \\
\hline & $06 / 13 / 2008-10 / 28 / 2008$ \\
\hline & $11 / 04 / 2008$ \\
\hline & $12 / 10 / 0208-12 / 11 / 2008$ \\
\hline & $12 / 13 / 2008-12 / 14 / 2008$ \\
\hline & $12 / 17 / 2008$ \\
\hline & $12 / 19 / 2008-12 / 22 / 2008$ \\
\hline & $12 / 24 / 2008-12 / 26 / 2008$ \\
\hline & $12 / 28 / 2008$ \\
\hline & 01/01/2009 \\
\hline & 01/03/2009-01/04/2009 \\
\hline & 01/07/2009 \\
\hline & 01/09/2009-01/14/2009 \\
\hline & 01/16/2009-02/03/2009 \\
\hline & 02/05/2009-02/12/2009 \\
\hline & $02 / 15 / 2009$ \\
\hline & $02 / 22 / 2009$ \\
\hline & $02 / 24 / 2009$ \\
\hline & 03/01/2009-07/05/2009 \\
\hline & 07/07/2009 \\
\hline & 07/09/2009 \\
\hline
\end{tabular}


Table 2-1. Missing data periods for real-time network of rain gages along West Branch DuPage River in and near DuPage County, Illinois, January 1, 2007, through September 30, 2013, in the WBDR13.WDM Watershed Data Management database.-Continued

[For more details, consult the corresponding annual U.S. Geological Survey (USGS) water data report at https://wdr.water.usgs.gov; site numbers correspond to figure 1; DSN, dataset number; Ill., Illinois; WWTF, wastewater treatment facility; Do., ditto]

\begin{tabular}{cc}
\hline Station data used to fill missing period (site number) & $\begin{array}{c}\text { Missing data period } \\
\text { (month/day/year) }\end{array}$ \\
\hline West Branch DuPage River near Naperville, III. (USGS gage 05540130; DSN 190)-Continued \\
Naperville Municipal Building. at Naperville, Ill. (Site 31)—Continued & $07 / 12 / 2009$ \\
$07 / 26 / 2009$ \\
$07 / 28 / 2009$ \\
$08 / 02 / 2009-08 / 18 / 2009$ \\
$08 / 22 / 2009-08 / 26 / 2009$ \\
$08 / 28 / 2009-09 / 30 / 2009$ \\
$10 / 01 / 2009-06 / 28 / 2010$ \\
$10 / 16 / 2010-02 / 18 / 2011$ \\
$06 / 07 / 2011-06 / 14 / 2011$ \\
$09 / 20 / 2011-09 / 30 / 2011$ \\
$10 / 01 / 2011-11 / 10 / 2011$ \\
$12 / 08 / 2011-02 / 02 / 2012$ \\
$05 / 06 / 2012-05 / 15 / 2012$ \\
$10 / 24 / 2012-11 / 14 / 2012$ \\
$12 / 08 / 2011-02 / 02 / 2012$ \\
$05 / 06 / 2012-05 / 15 / 2012$ \\
$10 / 24 / 2012-11 / 14 / 2012$ \\
\hline
\end{tabular}


Table 2-2. Snowfall-affected periods for real-time network of rain gages along West Branch DuPage River, in and near DuPage County, Illinois, stored in the WBDR13.WDM Watershed Data Management database, January 1, 2007September 30, 2013.

[For more details, consult the corresponding annual U.S. Geological Survey (USGS) water data report at https://wdr.water.usgs.gov; site numbers correspond to figure 1; Ill., Illinois; DSN, dataset number; WWTF, wastewater treatment facility]

\begin{tabular}{|c|c|c|}
\hline \multicolumn{3}{|c|}{ Snow-affected periods (month/day/year) for Naperville Municipal Building at Naperville, III. (Site 31; DSN 131) } \\
\hline 01/06/2007-01/07/2007 & $12 / 10 / 2010-12 / 11 / 2010$ & 02/07/2012-02/08/2012 \\
\hline 01/14/2007-01/15/2007 & $12 / 20 / 2010$ & 02/10/2012-02/11/2012 \\
\hline $01 / 21 / 2007$ & $12 / 24 / 2010-12 / 26 / 2010$ & $02 / 13 / 2012-02 / 13 / 2012$ \\
\hline 02/12/2007-02/13/2007 & $12 / 29 / 2010-12 / 30 / 2010$ & $02 / 20 / 2012-02 / 21 / 2012$ \\
\hline $02 / 17 / 2007$ & $01 / 11 / 2011-01 / 12 / 2011$ & $02 / 23 / 2012-02 / 24 / 2012$ \\
\hline 02/24/2007-02/25/2007 & $01 / 22 / 2011$ & $12 / 26 / 2012-12 / 29 / 2012$ \\
\hline 03/09/2007 & $01 / 24 / 2011$ & $01 / 20 / 2013-01 / 21 / 2013$ \\
\hline $12 / 03 / 2009-12 / 10 / 2009$ & 01/27/2011-01/29/2011 & $01 / 23 / 2013-01 / 25 / 2013$ \\
\hline $12 / 18 / 2009-12 / 28 / 2009$ & 02/01/2011-02/02/2011 & $01 / 30 / 2013-02 / 10 / 2013$ \\
\hline $12 / 30 / 2009-12 / 31 / 2009$ & $02 / 06 / 2011$ & $02 / 18 / 2013-02 / 19 / 2013$ \\
\hline 01/06/2010-01/08/2010 & $02 / 08 / 2011$ & $02 / 21 / 2013-03 / 02 / 2013$ \\
\hline 01/10/2010-01/12/2010 & $02 / 12 / 2011$ & 03/04/2013-03/08/2013 \\
\hline 01/14/2010-01/21/2010 & $02 / 15 / 2011$ & 03/11/2013-03/12/2013 \\
\hline 01/24/2010-01/28/2010 & $02 / 22 / 2011-02 / 28 / 2011$ & 03/18/2013-03/21/2013 \\
\hline 02/01/2010-02/03/2010 & 03/06/2011 & \\
\hline 02/05/2010-02/06/2010 & 11/09/2011-11/10/2011 & \\
\hline 02/08/2010-02/10/2010 & 11/27/2011-11/28/2011 & \\
\hline 02/15/2010-02/16/2010 & $12 / 08 / 2011-12 / 09 / 2011$ & \\
\hline 02/19/2010-02/28/2010 & $12 / 16 / 2011-12 / 17 / 2011$ & \\
\hline 03/01/2010 & $01 / 12 / 2012-01 / 12 / 2012$ & \\
\hline 03/19/2010-03/21/2010 & 01/18/2012-01/22/2012 & \\
\hline $12 / 04 / 2010-12 / 05 / 2010$ & 01/27/2012-01/28/2012 & \\
\hline \multicolumn{3}{|c|}{ Snow-affected periods (month/day/year) for Wheaton Water Department at Wheaton, III. (Site 33; DSN 133) } \\
\hline 01/06/2007-01/07/2007 & $01 / 20 / 2010-01 / 21 / 2010$ & $02 / 01 / 2011-02 / 02 / 2011$ \\
\hline 01/14/2007-01/15/2007 & $01 / 25 / 2010-02 / 12 / 2010$ & 02/06/2011-02/08/2011 \\
\hline 01/18/2007-01/19/2007 & $02 / 15 / 2010-02 / 16 / 2010$ & $02 / 11 / 2011-02 / 12 / 2011$ \\
\hline $01 / 21 / 2007$ & 02/19/2010-03/03/2010 & $02 / 20 / 2011-02 / 23 / 2011$ \\
\hline $02 / 06 / 2007$ & 03/19/2010-03/21/2010 & $02 / 25 / 2011-02 / 28 / 2011$ \\
\hline 02/12/2007-02/13/2007 & 04/08/2010-04/09/2010 & $03 / 05 / 2011$ \\
\hline $02 / 17 / 2007$ & $12 / 09 / 2010$ & 03/10/2011 \\
\hline 02/24/2007-02/26/2007 & $12 / 11 / 2010-12 / 13 / 2010$ & 03/24/2011-03/26/2011 \\
\hline $02 / 28 / 2007$ & $12 / 16 / 2010$ & 04/16/2011-04/18/2011 \\
\hline 03/03/2007 & $12 / 20 / 2010-12 / 22 / 2010$ & \\
\hline 03/06/2007 & $12 / 24 / 2010-12 / 26 / 2010$ & \\
\hline 03/09/2007 & $12 / 29 / 2010-12 / 30 / 2010$ & \\
\hline 11/25/2009-11/27/2009 & $01 / 01 / 2011$ & \\
\hline $12 / 03 / 2009-12 / 10 / 2009$ & 01/05/2011-01/08/2011 & \\
\hline $12 / 12 / 2009-12 / 13 / 2009$ & 01/11/2011-01/20/2011 & \\
\hline 12/17/2009-01/18/2010 & $01 / 22 / 2011-01 / 31 / 2011$ & \\
\hline
\end{tabular}


Table 2-2. Snowfall-affected periods for real-time network of rain gages along West Branch DuPage River, in and near DuPage County, Illinois, stored in the WBDR13.WDM Watershed Data Management database, January 1, 2007September 30, 2013.-Continued

[For more details, consult the corresponding annual U.S. Geological Survey (USGS) water data report at https://wdr.water.usgs.gov; site numbers correspond to figure 1; Ill., Illinois; DSN, dataset number; WWTF, wastewater treatment facility]

\begin{tabular}{|c|c|c|c|}
\hline \multicolumn{4}{|c|}{ Snow-affected periods (month/day/year) for Wheaton Sewer Department at Wheaton, III. (Site 34; DSN 134) } \\
\hline 01/06/2007-01/07/2007 & 03/19/2010-03/21/2010 & $02 / 20 / 2011-02 / 23 / 2011$ & $01 / 23 / 2013-01 / 25 / 2013$ \\
\hline 01/14/2007-01/15/2007 & $04 / 08 / 2010-04 / 09 / 2010$ & 02/25/2011-02/28/2011 & $01 / 27 / 2013$ \\
\hline $01 / 21 / 2007$ & $11 / 24 / 2010$ & $03 / 05 / 2011$ & 01/30/2013-02/05/2013 \\
\hline $02 / 06 / 2007$ & $11 / 30 / 2010$ & 03/10/2011 & 02/04/2013-02/08/2013 \\
\hline 02/12/2007-02/13/2007 & $12 / 01 / 2010$ & 03/23/2011-03/25/2011 & $02 / 11 / 2013$ \\
\hline $02 / 17 / 2007$ & $12 / 03 / 2010-12 / 06 / 2010$ & $04 / 16 / 2011$ & $02 / 15 / 2013-02 / 16 / 2013$ \\
\hline 02/24/2007-02/25/2007 & $12 / 09 / 2010$ & $04 / 18 / 2011$ & 02/18/2013-02/19/2013 \\
\hline 03/06/2007 & $12 / 11 / 2010-12 / 13 / 2010$ & $11 / 12 / 2012$ & $02 / 21 / 2013-02 / 23 / 2013$ \\
\hline 03/09/2007 & $12 / 16 / 2010$ & $11 / 23 / 2012$ & 02/26/2013-03/02/2013 \\
\hline 11/25/2009-11/26/2009 & $12 / 20 / 2010-12 / 22 / 2010$ & $12 / 09 / 2012-12 / 11 / 2012$ & 03/04/2013-03/06/2013 \\
\hline 12/03/2009-12/10/2009 & $12 / 24 / 2010-12 / 26 / 2010$ & $12 / 15 / 2012$ & 03/06/2013 \\
\hline $12 / 12 / 2009-12 / 13 / 2009$ & $01 / 01 / 2011$ & $12 / 20 / 2012-12 / 21 / 2012$ & 03/11/2013-03/14/2013 \\
\hline 12/17/2009-01/12/2010 & 01/05/2011-01/08/2011 & $12 / 24 / 2012-12 / 29 / 2012$ & 03/16/2013 \\
\hline 01/15/2010-01/18/2010 & 01/11/2011-01/20/2011 & $01 / 03 / 2013$ & 03/15/2013-03/20/2013 \\
\hline 01/20/2010-01/21/2010 & 01/22/2011-01/31/2011 & $01 / 05 / 2013$ & 03/24/2013-03/25/2013 \\
\hline 01/24/2010-02/12/2010 & $02 / 01 / 2011-02 / 02 / 2011$ & 01/12/2013-01/13/2013 & \\
\hline 02/15/2010-02/16/2010 & 02/06/2011-02/08/2011 & $01 / 16 / 2013$ & \\
\hline 02/19/2010-03/03/2010 & $02 / 11 / 2011-02 / 12 / 2011$ & $01 / 21 / 2013$ & \\
\hline \multicolumn{4}{|c|}{ Snow-affected periods (month/day/year) for Bartlett WWTF near Bartlett, III. (Site 40; DSN 140) } \\
\hline 01/06/2007-01/07/2007 & $01 / 17 / 2008-01 / 27 / 2008$ & $03 / 29 / 2009$ & $01 / 18 / 2012-01 / 22 / 2012$ \\
\hline 01/14/2007-01/16/2007 & $01 / 29 / 2008-02 / 03 / 2008$ & $11 / 25 / 2009-11 / 26 / 2009$ & 01/27/2012-01/29/2012 \\
\hline 01/19/2007-01/20/2007 & $02 / 05 / 2008-02 / 13 / 2008$ & $02 / 23 / 2010-02 / 27 / 2010$ & 02/07/2012-02/08/2012 \\
\hline $01 / 22 / 2007$ & $02 / 15 / 2008$ & 03/19/2010-03/21/2010 & 02/10/2012-02/11/2012 \\
\hline $02 / 12 / 2007$ & $02 / 18 / 2008-02 / 22 / 2008$ & $12 / 04 / 2010-12 / 05 / 2010$ & $02 / 13 / 2012-02 / 15 / 2012$ \\
\hline $02 / 14 / 2007$ & $02 / 25 / 2008-02 / 29 / 2008$ & $12 / 10 / 2010-12 / 11 / 2010$ & $02 / 20 / 2012-02 / 21 / 2012$ \\
\hline $02 / 17 / 2007$ & $03 / 04 / 2008$ & $12 / 20 / 2010-12 / 21 / 2010$ & $02 / 23 / 2012-02 / 24 / 2012$ \\
\hline 02/25/2007-02/26/2007 & 03/06/2008-03/10/2008 & $12 / 24 / 2010-12 / 26 / 2010$ & $02 / 26 / 2012$ \\
\hline $02 / 28 / 2007$ & $03 / 21 / 2008-03 / 22 / 2008$ & $12 / 29 / 2010$ & $12 / 26 / 2012-12 / 29 / 2012$ \\
\hline $03 / 03 / 2007$ & $03 / 27 / 2008$ & 01/11/2011-01/12/2011 & 01/30/2013-02/04/2013 \\
\hline $03 / 07 / 2007$ & $11 / 24 / 2008$ & 01/22/2011-01/24/2011 & 02/06/2013-02/09/2013 \\
\hline 03/09/2007 & $11 / 30 / 2008$ & 01/27/2011-01/28/2011 & $02 / 18 / 2013-02 / 19 / 2013$ \\
\hline $11 / 21 / 2007-11 / 22 / 2007$ & $12 / 03 / 2008-12 / 04 / 2008$ & 02/01/2011-02/02/2011 & $02 / 21 / 2013-02 / 22 / 2013$ \\
\hline $12 / 01 / 2007$ & $12 / 09 / 2008-12 / 10 / 2008$ & 02/06/2011 & $02 / 24 / 2013$ \\
\hline $12 / 04 / 2007-12 / 10 / 2007$ & $12 / 18 / 2008$ & $02 / 08 / 2011$ & 02/26/2013-03/02/2013 \\
\hline $12 / 15 / 2007-12 / 18 / 2007$ & $12 / 24 / 2008-12 / 25 / 2008$ & 02/22/2011-02/26/2011 & 03/04/2013-03/08/2013 \\
\hline $12 / 23 / 2007-12 / 24 / 2007$ & $01 / 22 / 2009$ & $02 / 28 / 2011$ & 03/11/2013-03/12/2013 \\
\hline $12 / 28 / 2007$ & $01 / 28 / 2009$ & 03/06/2011 & 03/18/2013-03/21/2013 \\
\hline $12 / 30 / 2007-01 / 02 / 2008$ & $02 / 14 / 2009$ & $12 / 08 / 2011-12 / 09 / 2011$ & \\
\hline $01 / 04 / 2008$ & $02 / 18 / 2009$ & $12 / 16 / 2011-12 / 17 / 2011$ & \\
\hline 01/14/2008-01/15/2008 & $02 / 22 / 2009$ & $01 / 12 / 2012-01 / 13 / 2012$ & \\
\hline
\end{tabular}


Table 2-2. Snowfall-affected periods for real-time network of rain gages along West Branch DuPage River, in and near DuPage County, Illinois, stored in the WBDR13.WDM Watershed Data Management database, January 1, 2007September 30, 2013.-Continued

[For more details, consult the corresponding annual U.S. Geological Survey (USGS) water data report at https://wdr.water.usgs.gov; site numbers correspond to figure 1; Ill., Illinois; DSN, dataset number; WWTF, wastewater treatment facility]

\begin{tabular}{|c|c|c|c|}
\hline \multicolumn{4}{|c|}{ Snow-affected periods (month/day/year) for Carol Stream WWTF at Carol Stream, III. (Site 44; DSN 144) } \\
\hline 01/06/2007-01/07/2007 & $02 / 01 / 2008$ & $12 / 18 / 2009-01 / 12 / 2010$ & $03 / 06 / 2011$ \\
\hline 01/14/2007-01/15/2007 & $02 / 04 / 2008$ & $01 / 15 / 2010-01 / 18 / 2010$ & $01 / 20 / 2012-01 / 21 / 2012$ \\
\hline $01 / 20 / 2007$ & 02/07/2008-02/08/2008 & $01 / 20 / 2010-01 / 21 / 2010$ & $01 / 27 / 2012-01 / 28 / 2012$ \\
\hline $01 / 22 / 2007$ & $02 / 12 / 2008-02 / 14 / 2008$ & $01 / 24 / 2010-02 / 12 / 2010$ & 02/07/2012-02/08/2012 \\
\hline $01 / 26 / 2007$ & $02 / 20 / 2008$ & $02 / 15 / 2010-02 / 16 / 2010$ & $02 / 10 / 2012-02 / 11 / 2012$ \\
\hline $02 / 17 / 2007$ & $02 / 22 / 2008$ & $02 / 19 / 2010-02 / 28 / 2010$ & $02 / 13 / 2012-02 / 14 / 2012$ \\
\hline 02/25/2007-02/28/2007 & $02 / 26 / 2008-02 / 29 / 2008$ & 03/01/2010-03/03/2010 & $02 / 20 / 2012-02 / 21 / 2012$ \\
\hline 03/02/2007 & $03 / 21 / 2008-03 / 22 / 2008$ & 03/19/2010-03/21/2010 & $02 / 23 / 2012-02 / 24 / 2012$ \\
\hline 03/07/2007 & $03 / 28 / 2008$ & 04/08/2010-04/09/2010 & $12 / 26 / 2012-12 / 29 / 2012$ \\
\hline 03/09/2007 & $12 / 08 / 2008$ & $12 / 04 / 2010-12 / 05 / 2010$ & $01 / 20 / 2013-01 / 21 / 2013$ \\
\hline 03/11/2007 & $12 / 10 / 2008$ & $12 / 10 / 2010-12 / 11 / 2010$ & $01 / 23 / 2013-01 / 26 / 2013$ \\
\hline $12 / 05 / 2007$ & $12 / 13 / 2008$ & $12 / 20 / 2010-12 / 22 / 2010$ & $01 / 30 / 2013-02 / 04 / 2013$ \\
\hline $12 / 07 / 2007$ & $12 / 18 / 2008$ & $12 / 24 / 2010-12 / 26 / 2010$ & $02 / 06 / 2013-02 / 08 / 2013$ \\
\hline $12 / 09 / 2007-12 / 10 / 2007$ & $12 / 20 / 2008$ & $12 / 29 / 2010-12 / 30 / 2010$ & $02 / 18 / 2013-02 / 19 / 2013$ \\
\hline $12 / 18 / 2007$ & $12 / 24 / 2008$ & 01/11/2011-01/12/2011 & $02 / 21 / 2013-02 / 22 / 2013$ \\
\hline $12 / 29 / 2007$ & $12 / 31 / 2008$ & $01 / 22 / 2011$ & $02 / 24 / 2013$ \\
\hline $12 / 31 / 2007-01 / 02 / 2008$ & $01 / 22 / 2009$ & $01 / 24 / 2011$ & $02 / 26 / 2013-03 / 02 / 2013$ \\
\hline $01 / 15 / 2008$ & 02/23/2009-02/24/2009 & 01/27/2011-01/28/2011 & 03/04/2013-03/07/2013 \\
\hline 01/18/2008-01/19/2008 & 03/29/2009 & 02/01/2011-02/02/2011 & $03 / 11 / 2013-03 / 12 / 2013$ \\
\hline 01/21/2008-01/22/2008 & $11 / 25 / 2009-11 / 27 / 2009$ & 02/06/2011-02/08/2011 & $03 / 18 / 2013-03 / 21 / 2013$ \\
\hline $01 / 24 / 2008$ & $12 / 03 / 2009-12 / 10 / 2009$ & 02/22/2011-02/26/2011 & \\
\hline $01 / 26 / 2008$ & $12 / 12 / 2009-12 / 15 / 2009$ & $02 / 28 / 2011$ & \\
\hline \multicolumn{4}{|c|}{ Snow-affected periods (month/day/year) for Blackwell Forrest Preserve near Warrenville, III. (Site 66; DSN 166) } \\
\hline 01/06/2007-01/07/2007 & $01 / 26 / 2008$ & $01 / 31 / 2009$ & $12 / 08 / 2011-12 / 09 / 2011$ \\
\hline 01/14/2007-01/15/2007 & 02/01/2008 & $02 / 23 / 2009$ & $12 / 16 / 2011-12 / 18 / 2011$ \\
\hline $01 / 20 / 2007$ & $02 / 04 / 2008$ & 03/29/2009 & $01 / 12 / 2012-01 / 13 / 2012$ \\
\hline $01 / 24 / 2007$ & 02/07/2008-02/08/2008 & $12 / 03 / 2009-12 / 04 / 2009$ & $01 / 18 / 2012-01 / 22 / 2012$ \\
\hline $01 / 26 / 2007$ & $02 / 10 / 2008$ & $12 / 06 / 2009-12 / 10 / 2009$ & $01 / 27 / 2012-01 / 28 / 2012$ \\
\hline $02 / 25 / 2007-02 / 28 / 2007$ & $02 / 12 / 2008-02 / 14 / 2008$ & $12 / 18 / 2009-12 / 28 / 2009$ & 02/07/2012-02/08/2012 \\
\hline 03/09/2007-03/10/2007 & $02 / 16 / 2008$ & $12 / 30 / 2009-12 / 31 / 2009$ & $02 / 10 / 2012-02 / 11 / 2012$ \\
\hline $12 / 05 / 2007$ & $02 / 20 / 2008$ & 01/06/2010-01/08/2010 & 02/13/2012-02/14/2012 \\
\hline $12 / 07 / 2007$ & $02 / 22 / 2008$ & $01 / 11 / 2010-01 / 12 / 2010$ & $02 / 20 / 2012-02 / 21 / 2012$ \\
\hline $12 / 09 / 2007-12 / 10 / 2007$ & $02 / 26 / 2008-02 / 27 / 2008$ & $01 / 25 / 2010-01 / 30 / 2010$ & $02 / 23 / 2012-02 / 24 / 2012$ \\
\hline $12 / 16 / 2007$ & $02 / 29 / 2008$ & 02/01/2010-02/03/2010 & $01 / 30 / 2013-02 / 04 / 2013$ \\
\hline $12 / 18 / 2007$ & $03 / 21 / 2008-03 / 22 / 2008$ & $02 / 05 / 2010-02 / 06 / 2010$ & 02/06/2013-02/08/2013 \\
\hline $12 / 29 / 2007$ & $03 / 28 / 2008$ & 02/08/2010-02/10/2010 & $02 / 18 / 2013-02 / 19 / 2013$ \\
\hline $12 / 31 / 2007-01 / 02 / 2008$ & $12 / 01 / 2008$ & $02 / 15 / 2010-02 / 16 / 2010$ & $02 / 21 / 2013-02 / 22 / 2013$ \\
\hline $01 / 15 / 2008$ & $12 / 08 / 2008$ & $02 / 19 / 2010-02 / 27 / 2010$ & $02 / 24 / 2013-03 / 02 / 2013$ \\
\hline 01/18/2008-01/19/2008 & $12 / 13 / 2008$ & 03/19/2010-03/20/2010 & 03/04/2013-03/08/2013 \\
\hline $01 / 21 / 2008-01 / 22 / 2008$ & $12 / 24 / 2008$ & 11/09/2011-11/10/2011 & $03 / 11 / 2013-03 / 12 / 2013$ \\
\hline $01 / 24 / 2008$ & $01 / 22 / 2009$ & $11 / 27 / 2011-11 / 28 / 2011$ & $03 / 18 / 2013-03 / 21 / 2013$ \\
\hline
\end{tabular}


Table 2-2. Snowfall-affected periods for real-time network of rain gages along West Branch DuPage River, in and near DuPage County, Illinois, stored in the WBDR13.WDM Watershed Data Management database, January 1, 2007September 30, 2013.-Continued

[For more details, consult the corresponding annual U.S. Geological Survey (USGS) water data report at https://wdr.water.usgs.gov; site numbers correspond to figure 1; Ill., Illinois; DSN, dataset number; WWTF, wastewater treatment facility]

\begin{tabular}{|c|c|c|c|}
\hline \multicolumn{4}{|c|}{ Snow-affected periods (month/day/year) for Kress Creek at West Chicago, III. (Site 89; DSN 189) } \\
\hline $01 / 14 / 2007-01 / 22 / 2007$ & $01 / 15 / 2008$ & 01/07/2009-01/15/2009 & $02 / 28 / 2010$ \\
\hline $01 / 24 / 2007$ & 01/17/2008-01/19/2008 & $01 / 28 / 2009$ & $12 / 04 / 2010-12 / 05 / 2010$ \\
\hline 01/26/2007-01/27/2007 & $01 / 21 / 2008-01 / 22 / 2008$ & 02/06/2009 & $12 / 10 / 2010-12 / 11 / 2010$ \\
\hline $01 / 29 / 2007$ & $01 / 24 / 2008$ & $02 / 14 / 2009$ & $12 / 20 / 2010$ \\
\hline $01 / 31 / 2007$ & $01 / 26 / 2008$ & $02 / 17 / 2009$ & $12 / 24 / 2010-12 / 26 / 2010$ \\
\hline $02 / 06 / 2007$ & 01/28/2008-01/30/2008 & $02 / 19 / 2009$ & $12 / 29 / 2010-12 / 31 / 2010$ \\
\hline 02/11/2007-02/14/2007 & $02 / 01 / 2008-02 / 02 / 2008$ & 02/21/2009-02/22/2009 & $02 / 23 / 2012-02 / 24 / 2012$ \\
\hline 02/17/2007-02/19/2007 & 02/04/2008-02/09/2008 & $02 / 24 / 2009$ & $12 / 26 / 2012-12 / 29 / 2012$ \\
\hline 02/25/2007-03/02/2007 & $02 / 12 / 2008-02 / 14 / 2008$ & 03/30/2009 & $01 / 10 / 2013$ \\
\hline $12 / 02 / 2007-12 / 03 / 2007$ & $02 / 20 / 2008$ & $04 / 06 / 2009$ & 01/20/2013-01/21/2013 \\
\hline $12 / 05 / 2007$ & $02 / 26 / 2008$ & $12 / 06 / 2009-12 / 14 / 2009$ & 01/23/2013-01/26/2013 \\
\hline $12 / 07 / 2007$ & $02 / 29 / 2008$ & $12 / 18 / 2009-12 / 27 / 2009$ & 01/30/2013-02/04/2013 \\
\hline $12 / 10 / 2007$ & 03/21/2008-03/23/2008 & $12 / 30 / 2009-01 / 01 / 2010$ & $02 / 06 / 2013$ \\
\hline $12 / 15 / 2007-12 / 16 / 2007$ & $11 / 17 / 2008$ & 01/06/2010-01/08/2010 & $02 / 08 / 2013$ \\
\hline $12 / 18 / 2007-12 / 20 / 2007$ & $11 / 24 / 2008$ & $01 / 14 / 2010-01 / 15 / 2010$ & 02/18/2013-02/19/2013 \\
\hline $12 / 23 / 2007-12 / 24 / 2007$ & $11 / 30 / 2008-12 / 03 / 2008$ & $01 / 22 / 2010-01 / 28 / 2010$ & $02 / 21 / 2013-02 / 22 / 2013$ \\
\hline $12 / 27 / 2007$ & $12 / 06 / 2008-12 / 10 / 2008$ & $02 / 01 / 2010-02 / 02 / 2010$ & $02 / 24 / 2013$ \\
\hline $12 / 29 / 2007$ & $12 / 13 / 2008-12 / 15 / 2008$ & $02 / 05 / 2010-02 / 06 / 2010$ & 02/26/2013-03/02/2013 \\
\hline $12 / 31 / 2007-01 / 02 / 2008$ & $12 / 17 / 2008$ & $02 / 08 / 2010-02 / 10 / 2010$ & 03/04/2013-03/12/2013 \\
\hline $01 / 05 / 2008$ & $12 / 19 / 2008-12 / 22 / 2008$ & $02 / 15 / 2010-02 / 16 / 2010$ & 03/18/2013-03/21/2013 \\
\hline $01 / 10 / 2008$ & $12 / 24 / 2008-12 / 27 / 2008$ & $02 / 19 / 2010-02 / 25 / 2010$ & \\
\hline \multicolumn{4}{|c|}{ Snow-affected periods (month/day/year) for West Branch DuPage River near Naperville, III. (Site 90; DSN 190) } \\
\hline 01/06/2007-01/07/2007 & $01 / 21 / 2008-01 / 23 / 2008$ & $12 / 09 / 2008$ & $12 / 26 / 2012-12 / 30 / 2012$ \\
\hline 01/13/2007-01/15/2007 & $01 / 25 / 2008$ & $12 / 15 / 2008-12 / 16 / 2008$ & 01/20/2013-01/21/2013 \\
\hline $01 / 26 / 2007$ & $01 / 29 / 2008$ & $12 / 23 / 2008$ & 01/23/2013-01/26/2013 \\
\hline 02/13/2007-02/14/2007 & 01/31/2008-02/02/2008 & $01 / 06 / 2009$ & 01/30/2013-01/31/2013 \\
\hline $2 / 19 / 2007$ & 02/07/2008-02/08/2008 & 02/13/2009-02/14/2009 & 02/01/2013-02/08/2013 \\
\hline 02/24/2007-02/28/2007 & 02/11/2008-02/12/2008 & $02 / 18 / 2009$ & 02/18/2013-02/19/2013 \\
\hline 03/09/2007 & $02 / 18 / 2008-02 / 21 / 2008$ & $02 / 21 / 2009$ & $02 / 21 / 2013-02 / 24 / 2013$ \\
\hline $03 / 15 / 2007$ & 02/25/2008-02/29/2008 & 02/22/2011-02/26/2011 & 02/26/2013-02/28/2013 \\
\hline $12 / 01 / 2007$ & 03/07/2008-03/08/2008 & $02 / 28 / 2011$ & 03/01/2013-03/02/2013 \\
\hline $12 / 03 / 2007-12 / 09 / 2007$ & 03/10/2008 & 03/06/2011 & 03/04/2013-03/06/2013 \\
\hline $12 / 15 / 2007-12 / 17 / 2007$ & 03/21/2008-03/22/2008 & 11/27/2011-11/28/2011 & 03/11/2013-03/12/2013 \\
\hline $12 / 23 / 2007-12 / 24 / 2007$ & $03 / 27 / 2008$ & 02/07/2012-02/08/2012 & 03/18/2013-03/21/2013 \\
\hline $12 / 28 / 2007$ & $11 / 16 / 2008-11 / 17 / 2008$ & $02 / 10 / 2012-02 / 11 / 2012$ & 04/19/2013-04/20/2013 \\
\hline $12 / 30 / 2007-01 / 02 / 2008$ & $11 / 30 / 2008-12 / 01 / 2008$ & $02 / 13 / 2012-02 / 14 / 2012$ & \\
\hline 01/14/2008-01/15/2008 & $12 / 03 / 2008$ & $02 / 20 / 2012-02 / 21 / 2012$ & \\
\hline 01/17/2008-01/18/2008 & $12 / 06 / 2008$ & $02 / 23 / 2012-02 / 24 / 2012$ & \\
\hline
\end{tabular}


Table 2-3. Descriptions of estimated and missing days in river stage data from U.S. Geological Survey streamgages along the West Branch DuPage River in and near DuPage County, Illinois, stored in the WBDR13.WDM Watershed Data Management database, for January 1, 2007, through September $30,2013$.

[For more details, consult the corresponding annual U.S. Geological Survey (USGS) water data report at https//wdr.water. usgs.gov; Ill., Illinois DSN, dataset number]

\begin{tabular}{|c|c|c|}
\hline $\begin{array}{l}\text { Station name } \\
\text { (site number) }\end{array}$ & $\begin{array}{l}\text { Missing period } \\
\text { (month/day/year) }\end{array}$ & $\begin{array}{l}\text { Estimated period } \\
\text { (month/day/year) }\end{array}$ \\
\hline $\begin{array}{l}\text { West Branch DuPage River near West Chicago, Ill. } \\
\text { (USGS gage 05539900; DSN 4990) }\end{array}$ & $\begin{array}{l}05 / 02 / 2013 \\
05 / 04 / 2013-05 / 06 / 2013\end{array}$ & None. \\
\hline $\begin{array}{l}\text { West Branch DuPage River near Warrenville, Ill. } \\
\text { (USGS gage 05540095; DSN 4950) }\end{array}$ & $\begin{array}{l}03 / 19 / 2010-03 / 23 / 2010 \\
07 / 22 / 2010-07 / 23 / 2010 \\
08 / 02 / 2010-08 / 03 / 2010 \\
08 / 24 / 2010-08 / 26 / 2010 \\
12 / 08 / 2010\end{array}$ & None. \\
\hline $\begin{array}{l}\text { Spring Brook at } 87^{\text {th }} \text { Street near Naperville, Ill. } \\
\text { (USGS gage 05540275; DSN 4750) }\end{array}$ & $\begin{array}{l}10 / 02 / 2011-10 / 03 / 2011 \\
10 / 05 / 2011-10 / 06 / 2011 \\
11 / 10 / 2011 \\
11 / 16 / 2011-11 / 17 / 2011 \\
11 / 19 / 2011-11 / 20 / 2011\end{array}$ & None. \\
\hline $\begin{array}{l}\text { West Branch DuPage River near Naperville, Ill. } \\
\text { (USGS gage 05540130; DSN 4130) }\end{array}$ & $\begin{array}{l}12 / 23 / 2006-12 / 27 / 2006 \\
02 / 04 / 2007-02 / 28 / 2007 \\
08 / 22 / 2007-08 / 23 / 2007 \\
12 / 06 / 2007-12 / 10 / 2007 \\
12 / 16 / 2007-12 / 18 / 2007 \\
01 / 01 / 2008-01 / 05 / 2008 \\
01 / 15 / 2008-02 / 22 / 2008 \\
12 / 05 / 2008-12 / 09 / 2008 \\
12 / 11 / 2008-12 / 13 / 2008 \\
12 / 15 / 2008-12 / 27 / 2008 \\
12 / 31 / 2008-02 / 09 / 2009 \\
02 / 19 / 2009-02 / 22 / 2009 \\
03 / 02 / 2009-03 / 04 / 2009 \\
10 / 01 / 2009\end{array}$ & None. \\
\hline $\begin{array}{l}\text { Kress Creek at West Chicago, Ill. } \\
\text { (USGS gage 05540060; DSN 4060) }\end{array}$ & $\begin{array}{l}12 / 30 / 2006-01 / 05 / 2007 \\
02 / 03 / 2007-02 / 08 / 2007 \\
03 / 01 / 2007-03 / 27 / 2007 \\
05 / 18 / 2008-05 / 22 / 2008 \\
12 / 30 / 2008-01 / 02 / 2009 \\
05 / 12 / 2011-05 / 17 / 2011 \\
05 / 21 / 2011-05 / 22 / 2011 \\
06 / 11 / 2011-06 / 12 / 2011 \\
06 / 26 / 2011-06 / 27 / 2011\end{array}$ & $\begin{array}{l}05 / 18 / 2011-05 / 20 / 2011 \\
05 / 23 / 2011-06 / 10 / 2011 \\
06 / 13 / 2011-06 / 25 / 2011 \\
06 / 28 / 2011-08 / 03 / 2011 \\
08 / 06 / 2011-08 / 07 / 2011 \\
05 / 25 / 2012-05 / 31 / 2012 \\
07 / 01 / 2012-07 / 24 / 2012 \\
09 / 06 / 2012-09 / 21 / 2012\end{array}$ \\
\hline
\end{tabular}


Table 2-4. Descriptions of estimated and missing days in river discharge data from U.S. Geological Survey streamgages along the West Branch DuPage River, in and near DuPage County, Illinois, stored in the WBDR13.WDM Watershed Data Management database, for January 1, 2007, through September 30, 2013.

[For more details, consult the corresponding annual U.S. Geological Survey (USGS) water data report at https://wdr. water.usgs.gov; Ill., Illinois; DSN, dataset number]

\begin{tabular}{|c|c|c|}
\hline $\begin{array}{l}\text { Station name } \\
\text { (site number) }\end{array}$ & $\begin{array}{l}\text { Missing period } \\
\text { (month/day/year) }\end{array}$ & $\begin{array}{l}\text { Estimated period } \\
\text { (month/day/year) }\end{array}$ \\
\hline $\begin{array}{l}\text { West Branch DuPage River near West Chicago, Ill. } \\
\text { (USGS gage 05539900; DSN 2990) }\end{array}$ & None & $\begin{array}{l}02 / 01 / 2007-02 / 19 / 2007 \\
01 / 04 / 2009-01 / 08 / 2009 \\
01 / 15 / 2009-01 / 19 / 2009 \\
01 / 22 / 2009-02 / 02 / 2009 \\
12 / 12 / 2009-12 / 13 / 2009 \\
01 / 02 / 2013 \\
05 / 02 / 2013 \\
05 / 04 / 2013-05 / 06 / 2013\end{array}$ \\
\hline $\begin{array}{l}\text { West Branch DuPage River near Warrenville, Ill. } \\
\text { (USGS gage 05540095; DSN 2950) }\end{array}$ & None & $\begin{array}{l}02 / 01 / 2007-02 / 19 / 2007 \\
01 / 21 / 2008-01 / 26 / 2008 \\
01 / 16 / 2009-01 / 20 / 2009 \\
08 / 30 / 2009-09 / 19 / 2009 \\
03 / 16 / 2010-03 / 23 / 2010 \\
06 / 30 / 2010-07 / 24 / 2010 \\
08 / 02 / 2010-08 / 03 / 2010 \\
08 / 24 / 2010-08 / 26 / 2010 \\
12 / 08 / 2010 \\
06 / 28 / 2011-07 / 21 / 2011 \\
07 / 25 / 2012-08 / 25 / 2012 \\
12 / 02 / 2013\end{array}$ \\
\hline $\begin{array}{l}\text { Spring Brook at } 87^{\text {th }} \text { Street near Naperville, Ill. } \\
\text { (USGS gage } 05540275 \text {; DSN 2750) }\end{array}$ & None & $\begin{array}{l}02 / 02 / 2007-02 / 18 / 2007 \\
12 / 04 / 2007-12 / 07 / 2007 \\
12 / 17 / 2007-12 / 18 / 2007 \\
01 / 01 / 2008-01 / 04 / 2008 \\
01 / 15 / 2008-02 / 16 / 2008 \\
02 / 23 / 2008-03 / 01 / 2008 \\
01 / 14 / 2009-01 / 23 / 2009 \\
01 / 25 / 2009-01 / 29 / 2009 \\
01 / 27 / 2010 \\
12 / 15 / 2010-12 / 31 / 2010 \\
01 / 07 / 2011-02 / 15 / 2011 \\
10 / 02 / 2011-10 / 03 / 2011 \\
10 / 05 / 2011-10 / 06 / 2011 \\
11 / 16 / 2011-11 / 17 / 2011 \\
11 / 19 / 2011-11 / 20 / 2011 \\
01 / 20 / 2012-01 / 22 / 2012 \\
02 / 11 / 2012-02 / 12 / 2012\end{array}$ \\
\hline
\end{tabular}


Table 2-4. Descriptions of estimated and missing days in river discharge data from U.S. Geological Survey streamgages along the West Branch DuPage River, in and near DuPage County, Illinois, stored in the WBDR13.WDM Watershed Data Management database, for January 1, 2007, through September 30, 2013.-Continued

[For more details, consult the corresponding annual U.S. Geological Survey (USGS) water data report at https//wdr. water.usgs.gov; DSN, dataset number; Ill., Illinois]

\begin{tabular}{|c|c|c|}
\hline $\begin{array}{l}\text { Station name } \\
\text { (site number) }\end{array}$ & $\begin{array}{l}\text { Missing period } \\
\text { (month/day/year) }\end{array}$ & $\begin{array}{l}\text { Estimated period } \\
\text { (month/day/year) }\end{array}$ \\
\hline $\begin{array}{l}\text { West Branch DuPage River near Naperville, Ill. } \\
\text { (USGS gage 05540130; DSN 2130) }\end{array}$ & None & $\begin{array}{l}12 / 23 / 2006-12 / 27 / 2006 \\
01 / 28 / 2007-02 / 28 / 2007 \\
08 / 22 / 2007-08 / 23 / 2007 \\
12 / 06 / 2007-12 / 10 / 2007 \\
12 / 16 / 2007-12 / 18 / 2007 \\
01 / 01 / 2008-01 / 05 / 2008 \\
01 / 15 / 2008-02 / 22 / 2008 \\
12 / 05 / 2008-12 / 09 / 2008 \\
12 / 11 / 2008-12 / 13 / 2008 \\
12 / 15 / 2008-12 / 27 / 2008 \\
12 / 31 / 2008-02 / 09 / 2009 \\
02 / 19 / 2009-02 / 22 / 2009 \\
03 / 02 / 2009-03 / 04 / 2009 \\
10 / 01 / 2009 \\
12 / 12 / 2009 \\
12 / 17 / 2009 \\
12 / 31 / 2009-01 / 22 / 2010 \\
01 / 28 / 2010-02 / 19 / 2010 \\
06 / 16 / 2010-06 / 17 / 2010 \\
12 / 09 / 2010-12 / 30 / 2010 \\
01 / 12 / 2011-02 / 15 / 2011 \\
01 / 04 / 2012 \\
01 / 15 / 2012-01 / 16 / 2012 \\
01 / 21 / 2012-01 / 22 / 2012 \\
02 / 12 / 2012-02 / 13 / 2012 \\
01 / 04 / 2013-01 / 08 / 2013 \\
01 / 21 / 2013-01 / 27 / 2013\end{array}$ \\
\hline $\begin{array}{l}\text { Kress Creek at West Chicago, Ill. } \\
\quad \text { (USGS gage 05540060; DSN 2060) }\end{array}$ & None & $\begin{array}{l}12 / 30 / 16-01 / 05 / 2007 \\
02 / 01 / 2007-02 / 20 / 2007 \\
03 / 01 / 2007-03 / 27 / 2007 \\
12 / 05 / 2007-12 / 10 / 2007 \\
01 / 02 / 2008 \\
01 / 19 / 2008 \\
01 / 21 / 2008-01 / 26 / 2008 \\
02 / 11 / 2008-02 / 14 / 2008 \\
05 / 18 / 2008-05 / 22 / 2008 \\
12 / 30 / 2008-01 / 02 / 2009 \\
01 / 04 / 2009 \\
01 / 09 / 2009-01 / 17 / 2009 \\
01 / 21 / 2009-01 / 24 / 2009 \\
01 / 30 / 2009 \\
12 / 14 / 2009-12 / 23 / 2009 \\
01 / 03 / 2010-01 / 22 / 2010 \\
02 / 09 / 2010-02 / 13 / 2010 \\
02 / 18 / 2010-02 / 19 / 2010 \\
12 / 17 / 2010-12 / 28 / 2010 \\
01 / 11 / 2011-02 / 15 / 2011 \\
05 / 12 / 2011-08 / 07 / 2011 \\
05 / 25 / 2012-05 / 31 / 2012 \\
07 / 01 / 2012-07 / 24 / 2012 \\
09 / 06 / 2012-09 / 21 / 2012\end{array}$ \\
\hline
\end{tabular}


For additional information contact:

Director, Illinois Water Science Center

U.S. Geological Survey

405 North Goodwin Avenue

Urbana, IL 61801-2347

http://il.water.usgs.gov/ 



\section{$\frac{\mathbb{2}}{\mathbb{3}}$}

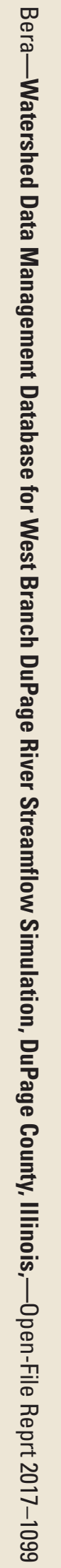

